\title{
18. INTERSTITIAL-WATER GEOCHEMISTRY OF KERGUELEN PLATEAU SEDIMENTS ${ }^{1}$
}

\author{
Steven R. Chambers ${ }^{2}$ and Ray E. Cranston ${ }^{3}$
}

\begin{abstract}
This report synthesizes all of the interstitial-water chemistry studies associated with the Kerguelen Plateau phase of ODP Leg 119. Sediments were cored at six sites $\left(49^{\circ} 24^{\prime} \mathrm{S}\right.$ to $\left.59^{\circ} 36^{\prime} \mathrm{S}\right)$ in water depths ranging from 564 to $4082 \mathrm{~m}$. A total of 77 interstitial-water samples was recovered as part of the routine sampling protocol. In addition, a novel, highresolution pore-water sampling program was tested during Leg 119 that enabled us to pinpoint reaction zones and extend our data base to deeper, drier levels that were heretofore inaccessible. Data collected include interstitial-water sodium, potassium, calcium, magnesium, pH, alkalinity, sulfate, ammonia, phosphate, aqueous silica, salinity, chloride, oxidation-reduction potentials, and sediment chemistry.

The northern sector (Sites 736 and 737) is characterized by the highest sedimentation rates (up to $140 \mathrm{~m} / \mathrm{m} . \mathrm{y}$.) and thermal gradients $\left(70^{\circ}-98^{\circ} \mathrm{C} / \mathrm{km}\right)$ encountered on the Kerguelen Plateau during Leg 119 . Site 737 represents the most reactive sediment column cored on the Kerguelen Plateau. Major cation fluxes at Site 737 are the strongest measured during Leg 119. High dissolved calcium concentrations $(141.5 \mathrm{mM})$ were encountered near the bottom of Hole 737B. Elevated temperatures promote silica diagenesis and the alteration of volcanic material below $300 \mathrm{mbsf}$, and a diagenetic front was discovered near 370 mbsf at Site 737.

The southern portion of the Kerguelen Plateau (Sites 738 and 744) records the lowest sedimentation rates (less than $5 \mathrm{~m} / \mathrm{m}$.y.) and thermal gradients $\left(43^{\circ} \mathrm{C} / \mathrm{km}\right)$ of the three study areas. Major cation fluxes at the southern sites are the lowest that we measured on the Kerguelen Plateau. High-resolution sampling provided evidence for significant silica release to the pore waters during the weathering of basement basalt. The relatively low thermal gradient does not appear to be sufficient for the formation of the opal-CT and quartz chert beds and nodules that were encountered below 120 mbsf at Site 738.

Sediment-accumulation rates on the Eastern Kerguelen Sediment Ridge (Sites 745 and 746) are intermediate to those of the northern and southern sites. Deposition below the regional CCD accounts for the nearly carbonate-free, siliceous sediments. Despite their low organic carbon contents $($ mean $=0.15 \%)$, sediments on the Eastern Kerguelen Sediment Ridge exhibit the highest pore-water alkalinity $(6.77 \mathrm{mM})$, ammonium $(0.50 \mathrm{mM})$, and phosphate $(23 \mu \mathrm{M})$ concentrations measured on the Kerguelen Plateau. Major cation fluxes are intermediate to those calculated for the northern and southern sites. The Eastern Kerguelen Sediment Ridge interstitial waters are unusual, however, in that the downward flux of magnesium is greater than the upward flux of calcium.
\end{abstract}

\section{INTRODUCTION}

Most of the solid phases present within the ocean are born to and destined to reside within a watery environment. Mantle magmas issue into the sea at mid-ocean ridges, creating new oceanic crust that gradually journeys away from the ridge and accumulates an apron of marine sediment. The sedimentary particles trap and bury seawater as they accumulate on the seafloor. Seawater thus trapped is known as "interstitial water," or "pore water." Solid and liquid phases in the marine environment are separable only in the sense that we can see them. In fact, they are constantly changing in concert, each phase reflecting the inexorable movement of the other toward an equilibrium with their slowly changing physical and chemical environment. This intimate relationship between solid and liquid is the central premise upon which geochemical studies of interstitial waters are based.

Chemical studies of sedimentary pore waters can provide valuable information on the chemical and physical stability of the uppermost portion of the ocean crust. Does an equilibrium exist between the interstitial waters, their surrounding sediments, the basement rocks below, and the ocean waters above? If not, how are they changing so as to approach an equilibrium state? The interstitial waters of marine sediments reside within a con-

\footnotetext{
${ }^{1}$ Barron, J., Larsen, B., et al., 1991. Proc. ODP, Sci. Results, 119: College Station, TX (Ocean Drilling Program).

2 Department of Geology, Stanford University, Stanford, CA 94305, U.S.A.

3 Geological Survey of Canada, Bedford Institute of Oceanography, Box 1006, Dartmouth, Nova Scotia, Canada B2Y 4A2.
}

duit that connects all of these crustal components, and, thus, provide a context within which the state of the system can be inferred. Assuming conservation of mass in a closed system, a net change in the composition of the solid phases must affect a change in the composition of the coexisting liquids. Likewise, the metabolic activities of microorganisms and macrofauna living below the sediment/water interface are generally recorded in the interstitial waters by the disappearance of oxidants, appearance of catabolic byproducts, and changes in the oxidation-reduction potential. Changes in the composition of pore fluids necessarily create chemical potential gradients that force the diffusional transport of solutes to and from reaction zones. In addition, compaction of sediments by overburden, lateral movement of lithospheric plates, and thermal fluxes within the crust are processes that can cause the movement and transformation of interstitial waters. Thus, a variety of crustal processes may be recorded in the waters trapped within marine sediments, but are we clever enough to read their chemical signature?

The interstitial-water geochemistry program of the Ocean Drilling Program (ODP) provides a unique opportunity to study the entire spectrum of solid-liquid interactions within the upper ocean crust. With over $9000 \mathrm{~m}$ of drill string available for coring, the JOIDES Resolution is capable of deep, continuous sediment (and pore-water) recovery in a broad variety of marine environments. Few other research vessels in the world are capable of sampling interstitial waters from the seafloor to the contact between sediments and basement rock. Such deep coring is a tremendous advantage in the attempt to determine the forces responsible for the present-day, vertical distribution of solutes in the pore fluids of marine sediments. 
The purposes of this report are to provide a synthesis of the interstitial-water chemistry studies conducted during ODP Leg 119 , to describe the regional variation of interstitial-water solute distributions on the Kerguelen Plateau, and to place these distributions in the context of the cumulative findings of Leg 119. Sediments were cored at six different Kerguelen Plateau sites $\left(49^{\circ} 24^{\prime} \mathrm{S}\right.$ to $\left.59^{\circ} 36^{\prime} \mathrm{S}\right)$ in water depths ranging from 564 to $4082 \mathrm{~m}$ (Fig. 1). One of the sites (738) was drilled through the entire sedimentary sequence to basement basalt. A total of 77 interstitialwater samples was recovered as part of the routine sampling protocol. In addition, a novel, high-resolution pore-water sampling program was tested during Leg 119 (see Cranston, this volume). Results from a variety of shipboard and shore-based analytical studies will be used to relate the interstitial-water chemistry to the diverse depositional environments and sedimentary sequences encountered on this cruise. As this represents a progress report of the Leg 119 interstitial-water program, problems that are being addressed by current research will also be indicated.

\section{METHODS}

\section{Sampling}

The interstitial-water geochemistry studies of the Kerguelen Plateau have had the unique benefit of two separate sampling programs. The standard ODP sampling protocol calls for one 5-10-cm-long whole-round minicore (approximately $170-340 \mathrm{~mL}$ ) to be taken every third core (approximately every $30 \mathrm{~m}$ ). This sampling program was carried out on Leg 119 with the result that 77 samples were obtained from Kerguelen Plateau cores for pore-water extraction. In addition, a new, high-resolution sampling technique was tested during Leg 119 (see Cranston, this volume). The high-resolution sampling called for $10-\mathrm{mL}$ sediment samples to be removed at 1-2 m intervals. The small size of the samples made frequent sampling feasible, and the technique allowed us to study the chemistry of interstitial waters in sections of the sediment column that were too dry to permit fluid extraction by normal methods. We feel that this technique merits serious consideration for future ODP cruises in that it provides a more detailed picture of the depth distribution of pore-water solutes, it is capable of providing data for the deeper portions of sediment columns that do not yield waters by the standard method, and it does not require wholesale removal of portions of the core. For a detailed description of the high-resolution technique and of the results that it produced, the reader is directed to the appropriate paper by Cranston in this volume. The results of the high-resolution study will be referred to in this report only when they supplement the data produced by the ODP interstitial-water geochemistry program. The remainder of this section describes analytical techniques employed in the study of samples from the latter program.

The ODP method for extracting interstitial waters from core samples involves a squeezing procedure incorporating a hydraulic press. Detailed descriptions of this procedure have been published elsewhere (Manheim, 1966; Manheim and Sayles, 1974). The whole-round core sample devoted to the pore-water program is cut from the parent core minutes after it appears on the drill rig floor. The sample is immediately retrieved to the chemistry laboratory. The core liner is removed and the outer surface of the sample is trimmed away in an attempt to ensure that only pristine sediment is squeezed. The sample is placed in a hydraulic press and loaded until an adequate amount of water is obtained. No effort is made to remove all of the pore-water (i.e., the amount of water extracted does not represent the true water content of the sample). The water is collected in syringes and filtered through a prewashed millipore filter with a nominal hole diameter of $0.45 \mu \mathrm{m}$. All of the samples are squeezed at room temperature and under normal atmospheric conditions.

Subsequent to issuance and filtration, the water samples were subsampled for shipboard and shore-based analytical work. A $5-\mathrm{mL}$ water sample was placed in a capped test tube and set aside in a refrigerator for shipboard analyses. Depending on the total amount obtained, 3-10 mL of water was used for $\mathrm{pH}$ and alkalinity measurements; the acidified samples were flame sealed in polyethylene tubes and sent to the ODP curator. An additional $4 \mathrm{~mL}$ of water was flame sealed in 2-mL glass ampoules for shore-based stable isotope and chemical analyses. Any remaining water was flame sealed in polyethylene tubing and shipped to the ODP curator.

The compressed sediment ("squeeze cake") was sampled for shipboard organic carbon and carbonate analyses and shorebased mineralogical and stable isotope studies. The shore-based solid-phase studies are being used to follow up interpretations put forth in this report and will be described at a later date.

\section{Analytical Methods}

Shipboard water chemistry included analyses for $\mathrm{pH}$, alkalinity, salinity, chloride, magnesium, calcium, sulfate, ammonium, phosphate, and aqueous silica. Details of the shipboard analytical methods have been published in a procedure manual (Gieskes and Peretsman, 1986). Salinity (total dissolved solids) determinations were made with an $\mathrm{AO}$ Scientific Instruments optical refractometer. Alkalinity and $\mathrm{pH}$ were determined by means of a Metrohm autotitrator, a Brinkman combination $\mathrm{pH}$ electrode, and a computer for data collection and Gran function calculations. Calcium and magnesium concentrations were measured by wet chemical titrations. Calcium was titrated with an EGTA solution and a GHA indicator, followed by quantitative extraction of the calcium-GHA complex with n-butanol. A total alkaline earth titration, using EDTA and eriochrome black-T indicator, yielded a magnesium concentration after subtraction of the total calcium concentration and application of a correction formula supplied by Gieskes and Peretsman (1986). Chloride concentrations were determined by wet chemical titration with a silver nitrate solution. A Dionex ion chromatograph supplied sulfate concentrations and a Bausch and Lomb Spectronic 1001 spectrophotometer yielded phosphate, ammonium, and aqueous silica concentrations. IAPSO (International Association for the Physical Sciences of the Ocean) standard seawater was the primary standard for calcium, magnesium, and sulfate determinations. The remaining analyses were standardized with prepared standards (see Gieskes and Peretsman, 1986).

Sodium and potassium analyses of the interstitial waters were determined using a shore-based Thermo Jarrell Ash 12E atomic absorption spectrophotometer. These analyses were conducted on samples transported from the ship in flame-sealed glass ampoules. Each sample was acidified to a $\mathrm{pH}$ of approximately 6 prior to analysis with Baker "Instra Analyzed" concentrated $\mathrm{HCl}$. Dilutions of about 200:1 and 100:1 were prepared for sodium and potassium analyses, respectively, using deionized and distilled water. To combat ionization interferences during sample combustion, a lithium nitrate solution was added to both samples and standards until a concentration of $1000 \mathrm{ppm}$ lithium was achieved. An air-acetylene flame was employed and absorptions were measured relative to the 330.2 and $769.9 \mathrm{~nm}$ wavelengths of sodium and potassium hollow cathode lamps, respectively.

Subsequent to freeze drying, small pieces of the squeezed sediments were removed for shipboard determinations of organic carbon and carbonate contents. A Coulometrics 5020 Total Carbon Apparatus coupled with a model $5010 \mathrm{CO}_{2}$ Coulometer was used for these analyses. 


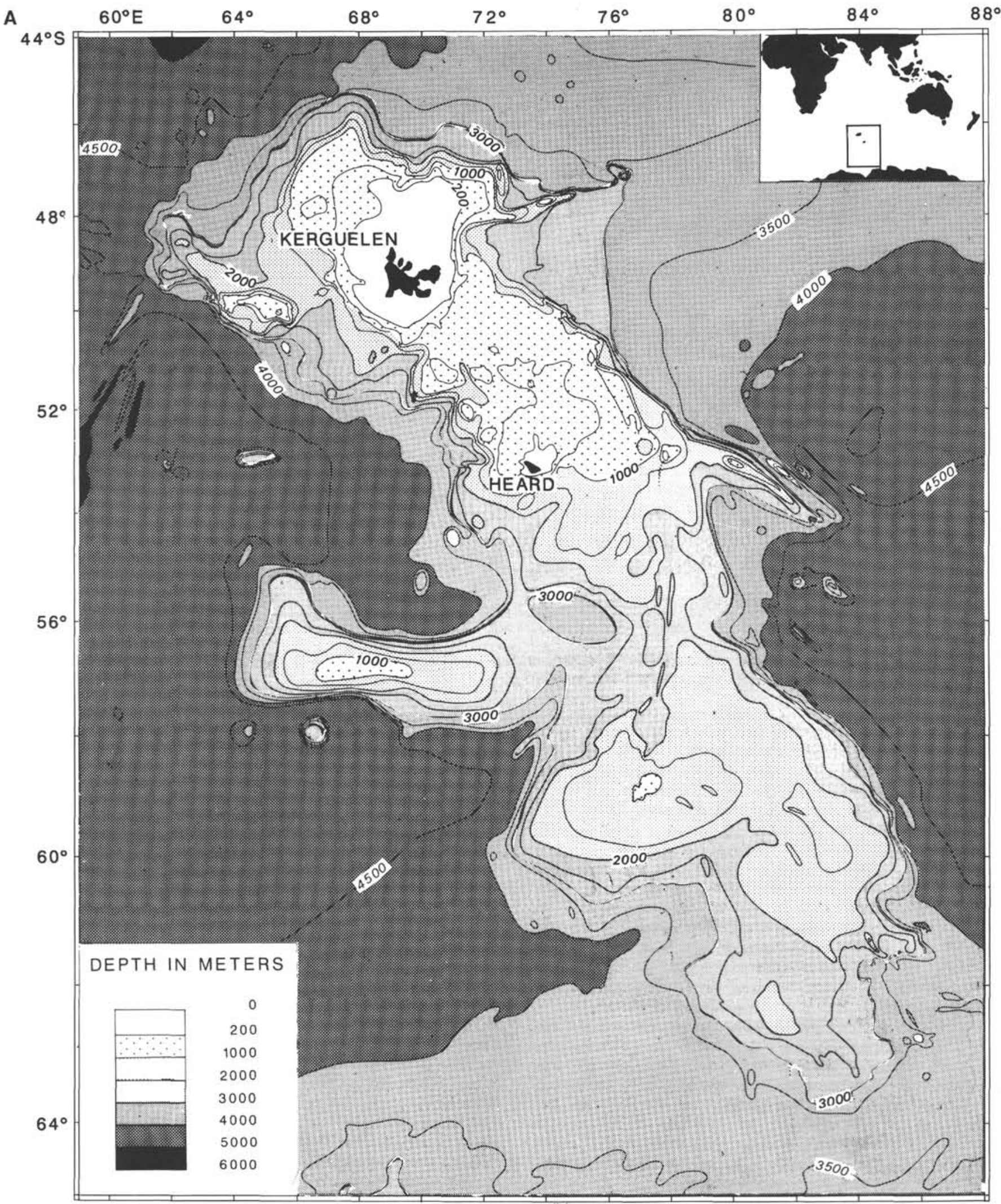

Figure 1. A. Bathymetric chart of the Kerguelen Plateau (Schlich, Wise, et al., 1989). The contour interval is $500 \mathrm{~m}$. B. Site locations for Leg 119 and Leg 120 with $1000 \mathrm{~m}$ bathymetry contours (Barron, Larsen, et al., 1989). 


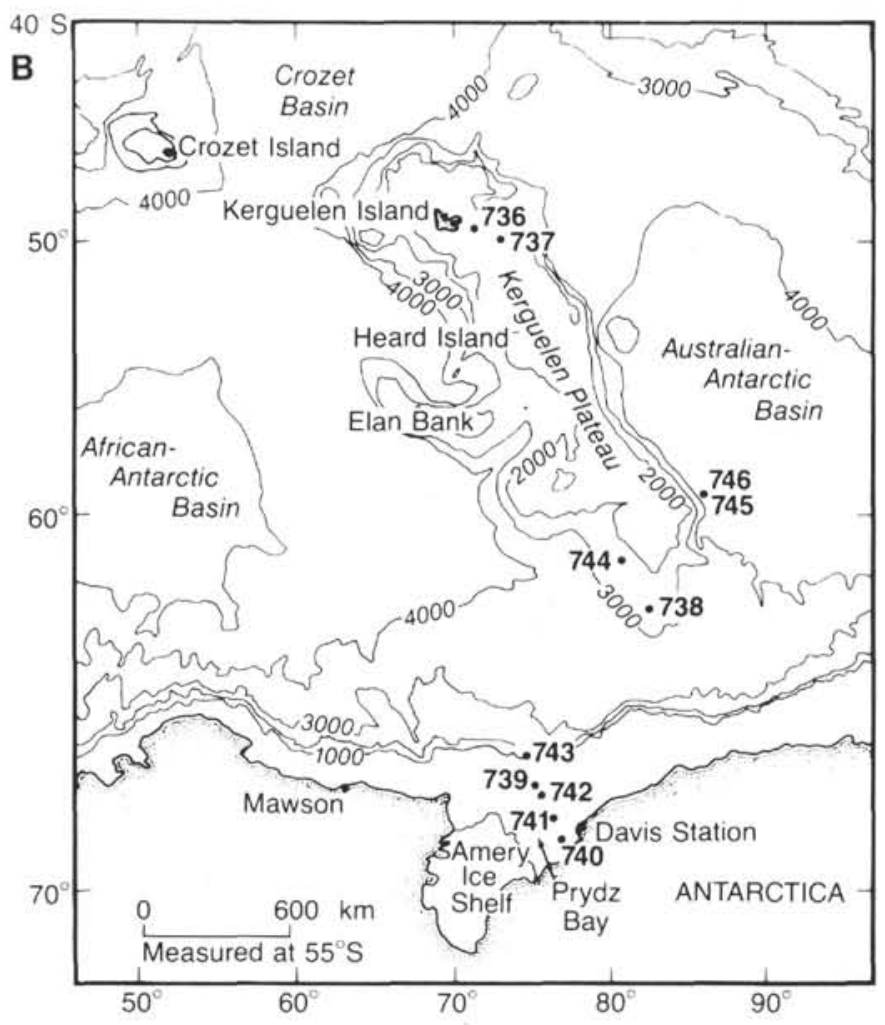

Figure 1 (continued).

\section{RESULTS}

Data produced in conjunction with the ODP interstitial-water geochemistry program for Leg 119 are listed in Tables 1, 2, and 3. Dissolved sodium, potassium, calcium, and magnesium concentrations are located in Table $1 ; \mathrm{pH}$, alkalinity, sulfate, ammonium, phosphate, and aqueous silica concentrations are shown in Table 2; and Table 3 contains salinity, chloride concentrations, and charge-balance data for the waters, as well as organic carbon and carbonate weight percentages of the squeezecake sediment samples.

In addition to the results of the high-resolution interstitialwater studies presented by Cranston (this volume), an exhaustive set of solid-phase chemical data for the coexisting sediments can be found in a separate data report (Cranston, this volume).

\section{Data Quality}

\section{Chemical Analyses}

Numerous replicate analyses of Leg 119 pore waters were conducted in an attempt to ascertain the amount of random error incorporated in the data set. Average fractional standard deviations for the entire data set were calculated as a measure of analytical precision (the number of replicate analyses is shown in parentheses): $\mathrm{Na}^{+}< \pm 3 \%(\mathrm{n}=67), \mathrm{Mg}^{2+} \pm 0.4 \%(\mathrm{n}=$ $69), \mathrm{Ca}^{2+} \pm 0.7 \%(\mathrm{n}=76), \mathrm{K}^{+}< \pm 2 \%(\mathrm{n}=36), \mathrm{Cl}^{-} \pm$ $0.5 \%(\mathrm{n}=107), \mathrm{SiO}_{2 \text { (aq) }}< \pm 2 \%(\mathrm{n}=46), \mathrm{NH}_{4}{ }^{+}< \pm 5 \%$ $(\mathrm{n}=80), \mathrm{PO}_{4}{ }^{3-} \pm 1 \%(\mathrm{n}=46)$. As an additional measure of the accuracy and precision of the analyses, charge-balance calculations for the data set are shown in Table 3. The charge imbalance was calculated as a percent of the total equivalent charge concentration:

$$
\begin{aligned}
\text { cations }= & {\left[\mathrm{Na}^{+}\right]+\left[\mathrm{K}^{+}\right]+2\left[\mathrm{Ca}^{2+}\right]+} \\
& 2\left[\mathrm{Mg}^{2+}\right]+\left[\mathrm{NH}_{4}^{+}\right]
\end{aligned}
$$

$$
\begin{aligned}
& \text { anions }=\left[\mathrm{Cl}^{-}\right]+\text {alkalinity }+2\left[\mathrm{SO}_{4}^{2-}\right]+ \\
& 2\left[\mathrm{HPO}_{4}{ }^{2-}\right] \text {, } \\
& \text { charge imbalance }=\frac{\text { cations }- \text { anions }}{\text { cations }+ \text { anions }} \times 100
\end{aligned}
$$

An excess of cations would have a positive charge imbalance by this convention. Using the average fractional standard deviations previously given and the composition of average seawater given by Drever (1982), a maximum charge imbalance of $\pm 2.3 \%$ due to systematic analytical error can be calculated. A glance at Table 3 shows that only 5 of the 68 samples for which charge imbalances were calculated are in excess of this value. The mean charge imbalance is $\pm 0.3 \%$ ( $n=68$ ), and the mean of the absolute values of the charge imbalances is $1.0 \%(\mathrm{n}=$ 68). It should be noted that data quality shows a positive correlation with time spent at sea! Gieskes et al. (1989) estimate the accuracy of the analytical procedures described in Gieskes and Peretsman (1986) as: $\mathrm{Ca}^{2+} \sim 2 \%, \mathrm{Mg}^{2+} \sim 2 \%, \mathrm{SO}_{4}^{2-} \sim 3 \%$, and $\mathrm{Cl}^{-} \sim 1 \%$.

\section{Sample Handling}

During the course of Leg 119, two major concerns about the quality of the ODP interstitial-water samples arose, namely drilling disturbance and the method of pore-fluid extraction. With respect to the former, how can we recognize samples that were contaminated during the drilling process? As for the latter, how closely do the water samples represent in-situ fluids given the well-known effects of temperature, pressure, and redox changes prior to extraction on the chemistry of interstitial waters?

The need for a means of recognizing drilling contamination became critical at Site 736 on the northern Kerguelen Plateau. Sedimentation rates were very high at Site $736(>50 \mathrm{~m} / \mathrm{m}$.y.; Barron, Larsen, et al., 1989) and the diatomaceous sediments recovered there are characterized by high porosities and water contents (up to $88 \%$ and $80 \%$, respectively; Barron, Larsen, et al., 1989). Many cores showed obvious signs of drilling disturbance, and, upon initiation of rotary coring, the samples developed a "soupy" consistency due to liquefaction. In this case, the drilling disturbance was obvious, but what are its effects on pore-fluid chemistry and can they be recognized?

The two possible sources of contamination during drilling are the surface seawater and drilling muds used to lubricate and cool the drill bit. A typical seawater sample from the region had the following characteristics:

$$
\begin{aligned}
& {\left[\mathrm{Cl}^{-}\right]=527 \mathrm{mM},} \\
& {\left[\mathrm{SiO}_{2(\mathrm{aq})}\right]=41 \mu \mathrm{M},} \\
& {\left[\mathrm{HPO}_{4}{ }^{2-}\right]=1 \mu \mathrm{M} .}
\end{aligned}
$$

We were also able to obtain a sample of the drilling mud for analysis. The water mixed with the mud had the composition:

$$
\begin{aligned}
& \text { Salinity }=5.0 \% 0 \\
& {\left[\mathrm{Ca}^{2+}\right]=0.6 \mathrm{mM},} \\
& {\left[\mathrm{SiO}_{2(\mathrm{aq})}\right]=179 \mu \mathrm{M},} \\
& {\left[\mathrm{HPO}_{4}^{2-}\right]=1 \mu \mathrm{M},} \\
& {\left[\mathrm{NH}_{4}^{+}\right]=\text {below detection }(<0.01 \mathrm{mM}) .}
\end{aligned}
$$

Contrary to the common assumption, some low-salinity water is injected into the hole during drilling with muds. Obviously, the effect of contamination depends on the amount and the composition of the contaminant. Drilling contamination will be discussed on a site-by-site basis in the discussion section. It became clear at Site 736, however, that only the grossest contaminations could be easily detected. A possible solution to this problem is 
Table 1. Interstitial water major cation concentrations for Leg 119 Kerguelen Plateau sites.

\begin{tabular}{cccccc}
\hline $\begin{array}{c}\text { Sample } \\
\text { (core, section) }\end{array}$ & $\begin{array}{c}\text { Depth } \\
(\mathrm{mbsf})\end{array}$ & $\begin{array}{c}\mathrm{Na}^{+} \\
(\mathrm{mM})\end{array}$ & $\begin{array}{c}\mathrm{Mg}^{2+} \\
(\mathrm{mM})\end{array}$ & $\begin{array}{c}\mathrm{Ca}^{2+} \\
(\mathrm{mM})\end{array}$ & $\begin{array}{c}\mathrm{K}^{+} \\
(\mathrm{mM})\end{array}$ \\
\hline
\end{tabular}

\begin{tabular}{rrrrrr}
\hline $119-736 \mathrm{~A}$ & & & & & \\
& & & & & \\
$1 \mathrm{H}-4$ & 5.95 & 498 & 51.6 & 10.1 & 11.7 \\
$3 \mathrm{H}-3$ & 22.95 & n.d. & 51.7 & 10.2 & n.d. \\
$8 \mathrm{H}-2$ & 40.95 & 499 & 54.0 & 10.5 & 11.0 \\
$9 \mathrm{H}-2$ & 55.95 & 492 & 53.1 & 10.4 & 11.0 \\
$13 \mathrm{H}-4$ & 85.45 & 485 & 54.8 & 10.8 & 11.0 \\
$18 \mathrm{H}-4$ & 113.95 & 495 & 54.0 & 10.1 & 11.1 \\
$20 \mathrm{H}-4$ & 152.25 & 490 & 53.5 & 10.0 & 10.8 \\
$23 \mathrm{X}-2$ & 177.95 & 484 & 52.3 & 9.9 & 10.5 \\
$28 \mathrm{X}-3$ & 208.35 & 515 & 52.5 & 9.9 & 11.0 \\
$29 \mathrm{X}-1$ & 234.35 & 497 & 53.4 & 9.8 & 10.4 \\
& & & & & \\
$119-736 \mathrm{C}$ & & & & & \\
& & & & & \\
$8 \mathrm{R}-1$ & 266.15 & 490 & 53.4 & 10.2 & 10.7 \\
$11 \mathrm{R}-3$ & 298.15 & 499 & 52.4 & 10.2 & 10.5 \\
$14 \mathrm{R}-2$ & 325.75 & 489 & 52.0 & 10.1 & 10.8 \\
$18 \mathrm{R}-2$ & 364.25 & 480 & 52.2 & 9.8 & 10.5 \\
& & & & & \\
$119-737 \mathrm{~A}$ & & & & & \\
& & & & & \\
$1 \mathrm{H}-2$ & 2.95 & 458 & 52.0 & 11.5 & 10.5 \\
$3 \mathrm{H}-4$ & 20.45 & 486 & 49.8 & 17.1 & 10.0 \\
$7 \mathrm{H}-4$ & 58.45 & 484 & 44.1 & 28.8 & 9.3 \\
$10 \mathrm{H}-4$ & 88.95 & 448 & 38.8 & 32.4 & 8.8 \\
$13 \mathrm{H}-4$ & 115.45 & 482 & 35.8 & 38.8 & 8.3 \\
$18 \mathrm{H}-4$ & 143.95 & n.d. & 32.4 & 44.8 & n.d. \\
$21 \mathrm{X}-1$ & 187.35 & 438 & 29.3 & 49.7 & 7.0 \\
$25 \mathrm{X}-3$ & 229.15 & 431 & 21.5 & 84.3 & 5.9 \\
& & & & &
\end{tabular}

$119-737 \mathrm{~B}$

$\begin{array}{lrrrrr}\text { 5R-2 } & 258.45 & 428 & 18.6 & 88.9 & 5.4 \\ \text { 8R-2 } & 285.45 & 413 & 14.4 & 79.4 & 4.0 \\ 11 \mathrm{R}-2 & 314.45 & 436 & 8.6 & 88.4 & 3.8 \\ 14 \mathrm{R}-2 & 347.80 & 413 & 5.8 & 98.8 & 3.2 \\ 17 \mathrm{R}-2 & 372.30 & 410 & 2.0 & 104.8 & 2.4 \\ 20 \mathrm{R}-4 & 404.30 & 379 & 1.5 & 127.5 & 1.8 \\ 23 \mathrm{R}-1 & 428.80 & 389 & 2.4 & 125.6 & 1.8 \\ 28 \mathrm{R}-4 & 482.30 & 374 & 3.5 & 125.8 & 1.8 \\ 29 \mathrm{R}-4 & 491.30 & 355 & 8.2 & 116.9 & 1.6 \\ 34 \mathrm{R}-5 & 541.00 & 337 & 5.8 & 128.4 & 1.1 \\ 37 \mathrm{R}-4 & 588.40 & 321 & 1.8 & 141.5 & 1.1 \\ 41 \mathrm{R}-5 & 808.50 & 337 & 3.8 & 135.6 & 1.0\end{array}$

119-738B

$\begin{array}{lrrrrr}1 \mathrm{H}-2 & 2.95 & 474 & 53.5 & 11.1 & 9.7 \\ 3 \mathrm{H}-5 & 20.95 & 489 & 53.8 & 11.4 & 10.0 \\ 7 \mathrm{H}-4 & 57.45 & 490 & 53.2 & 12.8 & 10.8 \\ 10 \mathrm{H}-2 & 82.95 & 445 & 51.5 & 13.9 & 10.1 \\ 13 \mathrm{H}-2 & 108.95 & 445 & 50.3 & 14.9 & 10.1 \\ 17 \mathrm{X}-3 & 141.85 & 457 & 48.5 & 18.5 & 9.4 \\ 20 \mathrm{X}-4 & 172.15 & 457 & 47.8 & 18.0 & 9.0 \\ 24 \mathrm{X}-2 & 207.55 & 458 & 47.1 & 19.5 & 8.7\end{array}$

to make in-situ sampling a routine procedure for the sake of comparison, but previous testing has shown that even this method of sampling is subject to drilling contamination (Suess, von Huene, et al., 1988). No in-situ samples were collected during Leg 119.

The effects of temperature changes prior to squeezing on the composition of interstitial waters are well documented (Mangelsdorf, et al., 1970; Bischoff et al., 1970; Fanning and Pilson, 1971; Sayles et al., 1973; de Lange, 1984). In general, when a sample is allowed to warm from seafloor temperatures (approximately $2^{\circ} \mathrm{C}$ ) to room temperature (approximately $22^{\circ} \mathrm{C}$ ) prior to loading the sediment, the concentrations of dissolved monovalent cations tend to increase, and the concentrations of dissolved divalent cations tend to decrease (Bischoff et al., 1970; Sayles et al., 1973). Leg 15 of the Deep Sea Drilling Project dedicated several holes to the testing of analytical and sampling
Table 1 (continued).

\begin{tabular}{|c|c|c|c|c|c|}
\hline $\begin{array}{c}\text { Sample } \\
\text { (core, section) }\end{array}$ & $\begin{array}{l}\text { Depth } \\
\text { (mbsf) }\end{array}$ & $\begin{array}{l}\mathrm{Na}^{+} \\
(\mathrm{mM})\end{array}$ & $\begin{array}{l}\mathrm{Mg}^{2+} \\
(\mathrm{mM})\end{array}$ & $\begin{array}{l}\mathrm{Ca}^{2+} \\
(\mathrm{mM})\end{array}$ & $\begin{array}{c}\mathrm{K}^{+} \\
(\mathrm{mM})\end{array}$ \\
\hline \multicolumn{6}{|l|}{$119-738 \mathrm{C}$} \\
\hline $4 \mathrm{R}-2$ & 218.85 & 458 & 48.7 & 20.1 & 9.0 \\
\hline $7 \mathrm{R}-3$ & 247.70 & 441 & 45.2 & 21.8 & 7.7 \\
\hline 10R-2 & 278.70 & 458 & 43.2 & 23.8 & 7.9 \\
\hline $18 \mathrm{R}-4$ & 337.50 & 450 & 41.0 & 28.0 & 7.1 \\
\hline $22 R-4$ & 395.50 & 489 & 38.5 & 30.7 & 8.8 \\
\hline \multicolumn{6}{|l|}{$119-744 \mathrm{~A}$} \\
\hline $1 \mathrm{H}-2$ & 2.95 & 490 & 52.5 & 11.0 & 10.1 \\
\hline $3 \mathrm{H}-3$ & 18.15 & 488 & 52.7 & 11.0 & 10.1 \\
\hline $4 \mathrm{H}-2$ & 28.15 & 480 & 52.5 & 11.7 & 10.2 \\
\hline $8 \mathrm{H}-3$ & 48.85 & 479 & 51.8 & 12.4 & 9.7 \\
\hline $10 \mathrm{H}-3$ & 84.85 & 484 & 50.0 & 14.2 & 9.8 \\
\hline $13 \mathrm{H}-4$ & 114.85 & 481 & 49.1 & 15.4 & 9.7 \\
\hline $18 \mathrm{H}-4$ & 143.15 & 489 & 48.7 & 18.7 & 9.4 \\
\hline $19 \mathrm{H}-4$ & 183.05 & 478 & 47.9 & 17.3 & 9.4 \\
\hline \multicolumn{6}{|l|}{ 119-744B } \\
\hline $2 \mathrm{H}-8$ & 18.39 & 477 & 52.7 & 11.2 & 10.3 \\
\hline \multicolumn{6}{|l|}{$119-744 \mathrm{C}$} \\
\hline $1 \mathrm{H}-1$ & 1.45 & n.d. & 52.7 & 10.7 & n.d. \\
\hline $1 \mathrm{H}-2$ & 2.95 & n.d. & 52.4 & 10.9 & n.d. \\
\hline $1 \mathrm{H}-3$ & 4.45 & n.d. & 51.8 & 11.0 & n.d. \\
\hline $1 \mathrm{H}-4$ & 5.95 & n.d. & 52.5 & 11.0 & n.d. \\
\hline $1 \mathrm{H}-5$ & 8.90 & n.d. & 53.9 & 11.3 & n.d. \\
\hline $2 \mathrm{H}-4$ & 12.95 & n.d. & 52.7 & 11.4 & n.d. \\
\hline $3 \mathrm{H}-4$ & 22.45 & n.d. & 52.7 & 11.5 & n.d. \\
\hline \multicolumn{6}{|l|}{$119-745 \mathrm{~A}$} \\
\hline $1 \mathrm{H}-5$ & 7.95 & 483 & 52.7 & 11.2 & 10.0 \\
\hline \multicolumn{6}{|l|}{$119-745 B$} \\
\hline $1 \mathrm{H}-2$ & 2.95 & 485 & 52.3 & 10.4 & 11.2 \\
\hline $3 \mathrm{H}-4$ & 20.45 & 487 & 51.9 & 11.9 & 9.7 \\
\hline $8 \mathrm{H}-4$ & 48.95 & 491 & 48.0 & 13.5 & 10.3 \\
\hline $9 \mathrm{H}-4$ & 77.45 & 478 & 48.0 & 15.1 & 8.9 \\
\hline $12 \mathrm{H}-4$ & 105.95 & 498 & 42.6 & 18.0 & 8.9 \\
\hline $14 \mathrm{H}-4$ & 124.95 & 481 & 40.7 & 18.7 & 8.5 \\
\hline $17 \mathrm{H}-4$ & 144.95 & 492 & 39.9 & 17.5 & 8.8 \\
\hline $19 \mathrm{H}-4$ & 183.95 & 488 & 38.2 & 18.0 & 8.4 \\
\hline $22 \mathrm{H}-4$ & 192.45 & 490 & 38.8 & 18.8 & 8.0 \\
\hline \multicolumn{6}{|l|}{$119-746 \mathrm{~A}$} \\
\hline $4 \mathrm{H}-4$ & 170.75 & 476 & 37.3 & 19.9 & 8.0 \\
\hline $7 \mathrm{H}-1$ & 194.75 & 487 & 35.2 & 20.4 & 7.8 \\
\hline $10 \mathrm{H}-4$ & 223.75 & 481 & 34.0 & 21.5 & 7.2 \\
\hline $13 X-4$ & 248.15 & 479 & 32.8 & 21.8 & 7.1 \\
\hline
\end{tabular}

techniques and recorded some of the largest temperature effects for potassium (up to $24 \%$ increase), and magnesium and calcium (up to $7 \%$ decrease; Sayles et al., 1973). Fanning and Pilson (1971) detected $40 \%-60 \%$ increases in the concentration of aqueous silica when the sample temperature was allowed to rise from $3^{\circ} \mathrm{C}$ to $21^{\circ}-23^{\circ} \mathrm{C}$. The effects of temperature change on the concentrations of major anions are very small (Bischoff et al., 1970) or nonexistent (Fanning and Pilson, 1971; Sayles et al., 1973). Shifts in ion exchange equilibria between clay minerals, zeolites, and interstitial waters are the postulated causes of the temperature change effects on dissolved cation concentrations (Mangelsdorf et al., 1970; Bischoff, et al., 1970; Gieskes, 1975). These reactions may be reversible (Mangelsdorf et al., 1970).

Pressure and temperature changes can affect carbonate equilibria and, in turn, the alkalinity and dissolved calcium concen- 
Table 2. Interstitial water nutrient data for Leg 119 Kerguelen Plateau sites.

\begin{tabular}{cccccccc}
\hline $\begin{array}{c}\text { Sample } \\
\text { (core, section) }\end{array}$ & $\begin{array}{c}\text { Depth } \\
(\mathrm{mbsf})\end{array}$ & $\mathrm{pH}$ & $\begin{array}{c}\text { Alkalinity } \\
(\mathrm{meq} / \mathrm{L})\end{array}$ & $\begin{array}{l}\mathrm{SO}_{4}^{2-} \\
(\mathrm{mM})\end{array}$ & $\begin{array}{c}\mathrm{NH}_{4}^{+} \\
(\mathrm{mM})\end{array}$ & $\begin{array}{c}\mathrm{PO}_{4}^{3-} \\
(\mu \mathrm{M})\end{array}$ & $\begin{array}{l}\mathrm{SiO}_{2} \\
(\mu \mathrm{M})\end{array}$ \\
\hline
\end{tabular}

119-736A

$\begin{array}{lrrrrrrr}1 \mathrm{H}-4 & 1.95 & 7.3 & 3.32 & 17.5 & 0.14 & 17 & 725 \\ 3 \mathrm{H}-3 & 22.95 & 7.7 & 5.00 & 24.8 & 0.28 & 13 & 767 \\ 8 \mathrm{H}-2 & 40.95 & 7.8 & 4.90 & 24.5 & 0.25 & 10 & 922 \\ 9 \mathrm{H}-2 & 55.95 & 7.8 & 4.58 & 25.7 & 0.25 & 8 & 838 \\ 13 \mathrm{H}-4 & 85.45 & 7.5 & 4.20 & 23.0 & 0.31 & 8 & 882 \\ 18 \mathrm{H}-4 & 113.95 & 7.8 & 4.17 & 25.4 & 0.33 & 4 & 984 \\ 20 \mathrm{H}-4 & 152.25 & 7.7 & 4.49 & 18.0 & 0.38 & 4 & 999 \\ 23 \mathrm{X}-2 & 177.95 & 7.8 & 4.28 & 24.8 & 0.41 & 3 & 990 \\ 28 \mathrm{X}-3 & 208.35 & 7.5 & 4.36 & 25.4 & 0.39 & 2 & 1001 \\ 29 \mathrm{X}-1 & 234.35 & 7.5 & 4.23 & 25.7 & 0.39 & 2 & 1130\end{array}$

$119-736 \mathrm{C}$

$\begin{array}{llllllll}8 R-1 & 286.15 & 7.5 & 4.77 & 24.8 & 0.39 & 4 & 1428 \\ 11 R-3 & 298.15 & 7.3 & 4.31 & 24.5 & 0.40 & 5 & 1939 \\ 14 R-2 & 325.75 & 7.2 & 3.99 & 24.8 & 0.38 & 5 & 1897 \\ 18 R-2 & 384.25 & 7.2 & 3.80 & 25.1 & 0.39 & 5 & 1943\end{array}$

119-737A

$1 \mathrm{H}-2$
$3 \mathrm{H}-4$
$7 \mathrm{H}-4$
$10 \mathrm{H}-4$
$13 \mathrm{H}-4$
$18 \mathrm{H}-4$
$21 \mathrm{X}-1$
$25 \mathrm{X}-3$

$\begin{array}{rll}2.95 & 7.5 & 2.74 \\ 20.45 & 7.4 & 2.29 \\ 58.45 & 7.4 & 1.87 \\ 88.95 & 7.4 & 1.38 \\ 115.45 & 7.3 & 1.17 \\ 143.95 & 7.4 & 1.17 \\ 187.35 & 7.5 & 1.17 \\ 229.15 & 7.3 & 0.92\end{array}$

$\begin{array}{ll}27.4 & 0.07 \\ 27.1 & 0.11 \\ 24.1 & 0.17 \\ 23.0 & 0.22 \\ 21.5 & 0.28 \\ 20.7 & 0.30 \\ 20.7 & 0.26 \\ 19.2 & 0.28\end{array}$

$\begin{array}{rr}3 & 576 \\ 0 & 717 \\ 0 & 858 \\ 0 & 1012 \\ 0 & 939 \\ 1 & 1240 \\ 0 & 1230 \\ 0 & 1269\end{array}$

$119-737 \mathrm{~B}$

$\begin{array}{lllllllr}\text { 5R-2 } & 258.45 & 7.3 & 0.74 & 18.9 & 0.33 & 0 & 1205 \\ \text { 8R-2 } & 285.45 & 7.3 & 0.83 & 18.1 & 0.25 & 0 & 1209 \\ 11 R-2 & 314.45 & 7.7 & 0.37 & 17.0 & 0.27 & 0 & 810 \\ 14 R-2 & 347.80 & 8.1 & 0.38 & 18.8 & 0.24 & 0 & 1053 \\ 17 R-2 & 372.30 & 8.2 & 0.28 & 11.8 & 0.25 & 0 & 1099 \\ 20 R-4 & 404.30 & 8.9 & 0.53 & 18.6 & 0.25 & 0 & 293 \\ 23 R-1 & 428.80 & 8.9 & 0.51 & 15.5 & 0.21 & 0 & 322 \\ 28 R-4 & 482.30 & 8.8 & 0.38 & 15.9 & 0.18 & 0 & 389 \\ 29 R-4 & 491.30 & 8.3 & 0.30 & 16.3 & 0.15 & 0 & 268 \\ 34 R-5 & 541.00 & 8.5 & 0.22 & 17.4 & 0.16 & 0 & 278 \\ 37 R-4 & 588.40 & 8.8 & 0.31 & 15.9 & 0.14 & 0 & 291 \\ 41 R-5 & 808.50 & 8.8 & 0.40 & 15.9 & 0.14 & 0 & 252\end{array}$

119-738B

$\begin{array}{lrllllll}1 \mathrm{H}-2 & 2.95 & 7.8 & 2.98 & 25.8 & 0.02 & 4 & 883 \\ 3 \mathrm{H}-5 & 20.95 & 7.8 & 2.82 & 25.5 & 0.01 & 1 & 607 \\ 7 \mathrm{H}-4 & 57.45 & 7.5 & 2.78 & 22.8 & 0.02 & 1 & 517 \\ 10 \mathrm{H}-2 & 82.95 & 7.5 & 2.70 & 23.7 & 0.02 & 0 & 548 \\ 13 \mathrm{H}-2 & 108.95 & 7.4 & 2.70 & 23.7 & 0.01 & 1 & 541 \\ 17 \mathrm{X}-3 & 141.85 & 7.4 & 2.50 & 24.0 & 0.01 & 1 & 689 \\ 20 \mathrm{X}-4 & 172.15 & 7.4 & 2.39 & 24.0 & 0.01 & 0 & 877 \\ 24 \mathrm{X}-2 & 207.55 & 7.4 & 2.53 & 23.4 & 0.01 & 0 & 558\end{array}$

tration of interstitial waters (Gieskes, 1973). Although less important to this study, the effects of an oxygenated atmosphere on the concentrations of sulfides and transition metals are well known.

How much do we compromise the quality of our data by processing the interstitial-water samples under ambient surface conditions? The compositions of ODP pore-fluid samples from the shallowest sediment layers are definitely different from their in-situ compositions. Any study of redox-sensitive elements is out of the question. On the other hand, ODP is a deep-drilling venture, and downhole temperatures as high or higher than room temperature are often encountered. Mangelsdorf et al. (1970) indicate that the magnitude of the temperature effect is proportional to the magnitude of the temperature change and that the
Table 2 (continued).

\begin{tabular}{|c|c|c|c|c|c|c|c|}
\hline $\begin{array}{c}\text { Sample } \\
\text { (core, section) }\end{array}$ & $\begin{array}{l}\text { Depth } \\
\text { (mbsf) }\end{array}$ & $\mathrm{pH}$ & $\begin{array}{l}\text { Alkalinity } \\
\text { (meq } / \mathrm{L})\end{array}$ & $\begin{array}{l}\mathrm{SO}_{4}^{2-} \\
(\mathrm{mM})\end{array}$ & $\begin{array}{l}\mathrm{NH}_{4}^{+} \\
(\mathrm{mM})\end{array}$ & $\begin{array}{c}\mathrm{PO}_{4}^{3-} \\
(\mu \mathrm{M})\end{array}$ & $\begin{array}{l}\mathrm{SiO}_{2} \\
(\mu \mathrm{M})\end{array}$ \\
\hline \multicolumn{8}{|l|}{$119-738 \mathrm{C}$} \\
\hline $4 \mathrm{R}-2$ & 218.85 & 7.3 & 2.71 & 23.7 & 0.01 & 1 & 592 \\
\hline $7 \mathrm{R}-3$ & 247.70 & 7.4 & 2.30 & 23.4 & 0.01 & 0 & 547 \\
\hline 10R-2 & 276.70 & 7.3 & 2.05 & 22.8 & 0.02 & 0 & 498 \\
\hline $18 R-4$ & 337.50 & 7.4 & 2.08 & 22.8 & 0.02 & 0 & 532 \\
\hline $22 R-4$ & 395.50 & 7.3 & 1.80 & 23.7 & 0.02 & 0 & 465 \\
\hline \multicolumn{8}{|l|}{$119-744 \mathrm{~A}$} \\
\hline $1 \mathrm{H}-2$ & 2.95 & 7.6 & 2.99 & 28.7 & 0.00 & 3 & 714 \\
\hline $3 \mathrm{H}-3$ & 18.15 & 7.5 & 2.51 & 28.7 & 0.01 & 1 & 596 \\
\hline $4 \mathrm{H}-2$ & 26.15 & 7.6 & 2.94 & 29.1 & 0.00 & 1 & 605 \\
\hline $6 \mathrm{H}-3$ & 46.65 & 7.5 & 2.74 & 27.6 & 0.01 & 0 & 605 \\
\hline $10 \mathrm{H}-3$ & 84.65 & 7.6 & 2.87 & 27.3 & 0.00 & 0 & 640 \\
\hline $13 \mathrm{H}-4$ & 114.65 & 7.4 & 2.73 & 28.4 & 0.00 & 0 & 656 \\
\hline $16 \mathrm{H}-4$ & 143.15 & 7.3 & 2.74 & 25.5 & 0.00 & 0 & 723 \\
\hline $19 \mathrm{H}-4$ & 163.05 & 7.3 & 2.79 & 28.4 & 0.00 & 0 & 620 \\
\hline \multicolumn{8}{|l|}{ 119-744B } \\
\hline $2 \mathrm{H}-6$ & 18.39 & 7.4 & 2.81 & 29.5 & 0.00 & 1 & 667 \\
\hline \multicolumn{8}{|l|}{$119-744 \mathrm{C}$} \\
\hline $1 \mathrm{H}-1$ & 1.45 & 7.5 & 2.85 & 29.1 & 0.00 & 4 & 718 \\
\hline $1 \mathrm{H}-2$ & 2.95 & 7.5 & 3.03 & 27.6 & 0.00 & 4 & 682 \\
\hline $1 \mathrm{H}-3$ & 4.45 & 7.5 & 3.02 & 27.6 & 0.01 & 2 & 672 \\
\hline $1 \mathrm{H}-4$ & 5.95 & 7.5 & 2.97 & 26.9 & 0.00 & 2 & 672 \\
\hline $1 \mathrm{H}-5$ & 6.90 & 7.5 & 3.00 & 31.3 & 0.01 & 2 & 732 \\
\hline $2 \mathrm{H}-4$ & 12.95 & 7.5 & 2.97 & 28.4 & 0.00 & 1 & 614 \\
\hline $3 \mathrm{H}-4$ & 22.45 & 7.4 & 2.82 & 27.3 & 0.00 & 1 & 612 \\
\hline \multicolumn{8}{|l|}{$119-745 \mathrm{~A}$} \\
\hline $1 \mathrm{H}-5$ & 7.95 & 7.5 & 4.00 & 29.4 & 0.10 & 20 & 689 \\
\hline \multicolumn{8}{|l|}{$119-745 B$} \\
\hline $1 \mathrm{H}-2$ & 2.95 & 7.5 & 3.39 & 29.4 & 0.03 & 13 & 735 \\
\hline $3 \mathrm{H}-4$ & 20.45 & 7.6 & 5.07 & 28.4 & 0.18 & 23 & 728 \\
\hline $6 \mathrm{H}-4$ & 48.95 & 7.6 & 6.28 & 25.9 & 0.31 & 18 & 794 \\
\hline $9 \mathrm{H}-4$ & 77.45 & 7.4 & 6.70 & 24.8 & 0.36 & 7 & 761 \\
\hline $12 \mathrm{H}-4$ & 105.95 & 7.4 & 6.77 & 23.2 & 0.40 & 4 & 913 \\
\hline $14 \mathrm{H}-4$ & 124.95 & 7.4 & 6.41 & 22.0 & 0.36 & 4 & 996 \\
\hline $17 \mathrm{H}-4$ & 144.95 & 7.5 & 6.11 & 21.6 & 0.39 & 4 & 946 \\
\hline $19 \mathrm{H}-4$ & 163.95 & 7.4 & 6.18 & 21.2 & 0.44 & 4 & 1005 \\
\hline $22 \mathrm{H}-4$ & 192.45 & 7.3 & 6.24 & 19.4 & 0.46 & 4 & 1010 \\
\hline \multicolumn{8}{|l|}{$119-746 \mathrm{~A}$} \\
\hline $4 \mathrm{H}-4$ & 170.75 & 7.4 & 4.86 & 21.2 & 0.50 & 2 & 948 \\
\hline $7 \mathrm{H}-1$ & 194.75 & 7.5 & 4.71 & 19.8 & 0.38 & 2 & 1017 \\
\hline $10 \mathrm{H}-4$ & 223.75 & 7.3 & 4.66 & 17.4 & 0.43 & 1 & 944 \\
\hline $13 X-4$ & 248.15 & 7.2 & 4.33 & 17.2 & 0.45 & 1 & 1054 \\
\hline
\end{tabular}

temperature effect may decrease and eventually undergo a reversal at depth. In addition, analyses of in-situ samples often yield data in good agreement with data from the normally processed samples (Moore and Gieskes, 1980; Suess, von Huene, et al., 1988). Thus, it may not be appropriate to squeeze all samples at low temperature.

We feel that the best solution would be to have one of the hydraulic presses on the Resolution fitted with a cooling jacket and a glove box for situations that call for analyses of surface sediment and/or redox-sensitive species. Routine in-situ sampling would also aid the verification of sample processing effects. It should be noted that all of the high-resolution samples were processed in a glove box and at low temperature (Cranston, this volume). 


\section{DISCUSSION}

\section{General Geologic Setting of the Kerguelen Plateau}

The Kerguelen Plateau is a submarine mountain range located on the Antarctic plate in the south-central Indian Ocean. Extending from $46^{\circ}$ to $64^{\circ} \mathrm{S}$ and from $62^{\circ}$ to $86^{\circ} \mathrm{E}$, the plateau measures approximately $2300 \mathrm{~km}$ along its long axis and ranges from 200 to $600 \mathrm{~km}$ in width (Fig. 1A; Schlich, Wise, et al., 1989). The northern portion of the plateau stands topographically high relative to the southern portion and contains its only subaerial features, Kerguelen, Heard, and McDonald islands. Water depths range from generally less than $1000 \mathrm{~m}$ on the northern Kerguelen plateau to more than $2000 \mathrm{~m}$ to the south. With the Antarctic Convergence (or Polar Front) positioned above its northern reaches, the Kerguelen Plateau lies beneath an Antarctic water mass that has been characterized by predominantly siliceous planktonic productivity since the initiation of Antarctic circumpolar circulation. High siliceous productivity and basaltic volcanism (as recently as $1 \mathrm{Ma}$ on Kerguelen Island; Houtz et al., 1977) have contributed to a cumulative sediment thickness of up to $3 \mathrm{~km}$ on the northern Kerguelen Plateau (Barron, Larsen, et al., 1989; Schlich, Wise, et al., 1989). In general, sedimentation rates have been higher to the north (Barron, Larsen, et al., 1989; Schlich, Wise, et al., 1989). The four basement penetrations on the southern Kerguelen Plateau during ODP Legs 119 and 120 recovered transitional mid-ocean ridge type basalt (T-MORB; Alibert, this volume; Schlich, Wise, et al., 1989). The oldest cored sediments are middle Cretaceous in age (Schlich, Wise, et al., 1989).

The following discussion will take the reader on a site-by-site tour through the interstitial waters of the Kerguelen Plateau by means of the samples collected during ODP Leg 119. For convenience, the six sites have been grouped into three localities (see Fig. 1): the northern Kerguelen Plateau (NKP; Sites 736 and 737), the southern Kerguelen Plateau (SKP; Sites 738 and 744), and the Eastern Kerguelen Sediment Ridge (Sites 745 and 746).

\section{Northern Kerguelen Plateau (Sites 736 and 737)}

Sites $736\left(49^{\circ} 24.12^{\prime} \mathrm{S}, 71^{\circ} 39.61^{\prime} \mathrm{E}\right)$ and $737\left(50^{\circ} 13.67^{\prime} \mathrm{S}\right.$, $\left.73^{\circ} 01.95^{\prime} \mathrm{E}\right)$ are located in a broad valley separating Kerguelen and Heard islands (Fig. 1B). A total of $1086.5 \mathrm{~m}$ of middle Eocene to Quaternary sediment was cored from five holes in waters less than $700 \mathrm{~m}$ deep. Their position underneath the Antarctic Convergence has subjected these sites to a relatively constant rain of biogenic silica since at least the middle Miocene (Barron, Larsen, et al., 1989). In addition, the growth and denudation of Kerguelen and Heard islands has shed a large amount of volcanic debris into this basin during the past $2.6 \mathrm{~m}$.y. (Barron, Larsen, et al., 1989).

High sedimentation rates on the NKP have produced a thick, insulating layer of sediments and relatively high thermal gradients. The continuous upper Pliocene to Quaternary diatomaceous section recovered at Site 736 accumulated at rates of 54140 m/m.y. (Barron, Larsen, et al., 1989). Diatom oozes, 140 $\mathrm{km}$ away at Site 737 , accumulated at a rate of $56 \mathrm{~m} / \mathrm{m} . \mathrm{y}$. from late Miocene to early Pliocene time, and upper Eocene to upper Oligocene nannofossil chalks reveal an uncompacted sedimentation rate of $28.1 \mathrm{~m} / \mathrm{m}$.y. (Barron, Larsen, et al., 1989). Neither site was cored to basaltic basement, but seismic stratigraphy indicates that total thicknesses of 2785 and $1465 \mathrm{~m}$ of sediment are present at Sites 736 and 737, respectively (Barron, Larsen, et al., 1989). These thick accumulations of sediment are at least partially responsible for the measured temperature gradients of $70^{\circ} \mathrm{C} / \mathrm{km}$ (Site 736 ) and $98^{\circ} \mathrm{C} / \mathrm{km}$ (Site 737) measured during Leg 119 (Barron, Larsen, et al., 1989).

\section{Site 736}

\section{Sediment Characteristics}

A continuous section of upper Pliocene to Quaternary diatom ooze with a variable content of volcanic debris was cored in $629 \mathrm{~m}$ of water at Site 736 . Leg 119 sedimentologists separated the sedimentary sequence into two stratigraphic units. Unit I comprises the upper $257 \mathrm{~m}$ of the section and consists of diatom ooze with up to $15 \%$ volcanic detritus. Unit II $(257-371 \mathrm{~m}$ below seafloor ) is a relatively pure diatom ooze. The abundance of volcanic material in Unit $I$ is apparent in the concentration vs. depth plots of aluminum, potassium, magnesium, iron, and manganese in sediments from the high-resolution sampling program (Fig. 2), which indicate higher concentrations of each of these elements in the uppermost $150 \mathrm{mbsf}$. Calcium carbonate contents are less than $10 \%$ in all but one of the samples that were analyzed (Fig. 3). The mean organic carbon concentration is $0.4 \%(\mathrm{~s} . \mathrm{d}=0.2 \%, \mathrm{n}=101)$ with a maximum of $1.43 \%$ (Table 3 ). The amount of organic matter tends to decrease with depth (Fig. 3) although the correlation is not strong ( $r=$ $-0.441, \mathrm{n}=101)$.

Drilling disturbance of the cores recovered at Site 736 was obvious during shipboard observations. Many of the cores had a soupy consistency produced by liquefaction during drilling. Significant variations in the shear strength and index properties of the sediments coincide with changes from advanced piston core (APC) to extended core barrel (XCB) and XCB to rotary core barrel (RCB) coring methods (Barron, Larsen, et al., 1989). Drilling disturbance appears to have caused the contamination of some of the interstitial-water samples.

\section{Interstitial-Water Chemistry}

A total of 101 samples was collected for interstitial-water chemical studies at Site 736. Of the 14 minicores obtained during routine ODP sampling, 7 were retrieved by the APC, 3 by the XCB, and 4 by the RCB coring methods. Physical-properties specialists noted that drilling disturbance increased as the drilling crew switched from the APC to the XCB and from the XCB to the RCB methods (Barron, Larsen, et al., 1989). The four RCB minicores had to be poured into the sample container of the hydraulic press because of their advanced state of liquefaction after rotary drilling. These observations prompt the obvious question: What, if any, effect did drilling have on the chemical composition of the pore-water samples?

The most common liquid contaminant employed in the drilling operation is surface seawater. Several chemical species that occur in seawater are highly reactive when trapped in the interstices of marine sediments because of the presence of microbes and unstable solid phases. For instance, if an adequate supply of reactive organic matter is available, anaerobic bacteria will begin to remove sulfate from pore waters after aerobic bacteria have consumed all of the available oxygen, nitrate, manganese, and iron. Phosphate and ammonium are byproducts of these catabolic processes. In addition, if biogenic silica is abundant in the sediments, dissolved silica concentrations will rise in the interstitial waters due to the instability of this material in the presence of seawater. Thus, the concentrations of sulfate, ammonium, phosphate, and silica tend to be quite different in seawater than in the pore waters of siliceous marine sediments.

The presence of a contaminant in the interstitial-water samples collected at Site 736 may be recorded in the concentrationvs.-depth profile of sulfate (Fig. 4). All of the samples from this site display a sulfate depletion relative to seawater, suggesting that anaerobic sulfate reduction is occurring below the sedimentwater interface. However, Samples 119-736A-1H-4 and 119-736A- 
Table 3. Sediment organic carbon and carbonate contents, interstitial water salinity and chloride concentrations, and porewater charge imbalance data for Leg 119 Kerguelen Plateau sites.

\begin{tabular}{|c|c|c|c|c|c|c|c|c|}
\hline $\begin{array}{c}\text { Sample } \\
\text { (core, section) }\end{array}$ & $\begin{array}{l}\text { Depth } \\
\text { (mbsf) }\end{array}$ & $\begin{array}{l}\text { Organic carbon } \\
\quad(\text { dry wt } \%)\end{array}$ & $\begin{array}{c}\mathrm{CaCO}_{3} \\
\text { (dry wt } \% \text { ) }\end{array}$ & $\begin{array}{l}\text { Salinity } \\
(\mathrm{g} / \mathrm{kg})\end{array}$ & $\underset{(\mathrm{mM})}{\mathrm{Cl}^{-}}$ & $\begin{array}{l}\text { Cations } \\
(\mathrm{meq} / \mathrm{L})\end{array}$ & $\begin{array}{l}\text { Anions } \\
(\mathrm{meq} / \mathrm{L})\end{array}$ & $\begin{array}{c}\text { Charge imbalance } \\
(\%)\end{array}$ \\
\hline \multicolumn{9}{|l|}{$119-736 \mathrm{~A}$} \\
\hline $1 \mathrm{H}-4$ & 5.95 & 0.62 & 4.0 & 35.0 & 556 & 633.1 & 594.4 & 3.2 \\
\hline $3 \mathrm{H}-3$ & 22.95 & 0.87 & 0.3 & 35.0 & 557 & n.d. & 611.5 & n.d. \\
\hline $6 \mathrm{H}-2$ & 40.95 & 0.62 & 1.2 & 35.0 & 562 & 638.7 & 615.8 & 1.8 \\
\hline $9 \mathrm{H}-2$ & 55.95 & 1.43 & 0.5 & 35.0 & 559 & 630.2 & 614.9 & 1.2 \\
\hline $13 \mathrm{H}-4$ & 85.45 & 0.90 & 2.7 & 36.0 & 556 & 626.3 & 606.1 & 1.6 \\
\hline $16 \mathrm{H}-4$ & 113.95 & 0.57 & 0.3 & 36.0 & 560 & 634.9 & 614.9 & 1.6 \\
\hline $20 \mathrm{H}-4$ & 152.25 & 1.02 & 0.1 & 36.0 & 559 & 627.7 & 595.6 & 2.6 \\
\hline $23 \mathrm{X}-2$ & 177.95 & 1.16 & 1.0 & 36.0 & 559 & 618.9 & 612.8 & 0.5 \\
\hline $26 X-3$ & 208.35 & 1.10 & 0.3 & 36.0 & 562 & 650.7 & 617.1 & 2.7 \\
\hline $29 X-1$ & 234.35 & 0.51 & 0.1 & 36.0 & 559 & 634.3 & 614.6 & 1.6 \\
\hline \multicolumn{9}{|l|}{$119-736 \mathrm{C}$} \\
\hline $8 \mathrm{R}-1$ & 266.15 & 0.40 & 7.0 & 36.0 & 560 & 628.1 & 614.3 & 1.1 \\
\hline $11 \mathrm{R}-3$ & 298.15 & 0.32 & 0.3 & 34.0 & 554 & 634.9 & 607.2 & 2.2 \\
\hline $14 \mathrm{R}-2$ & 325.75 & 0.35 & 6.7 & 35.0 & 545 & 624.7 & 598.5 & 2.1 \\
\hline $18 \mathrm{R}-2$ & 364.25 & 0.29 & 1.7 & 34.0 & 554 & 614.4 & 607.7 & 0.5 \\
\hline \multicolumn{9}{|l|}{$119-737 \mathrm{~A}$} \\
\hline $1 \mathrm{H}-2$ & 2.95 & 0.53 & 0.1 & 35.5 & 554 & 595.7 & 611.6 & -1.3 \\
\hline $3 \mathrm{H}-4$ & 20.45 & 0.49 & 0.5 & 36.5 & 558 & 609.8 & 614.4 & -0.4 \\
\hline $7 \mathrm{H}-4$ & 58.45 & 0.42 & 0.1 & 37.5 & 564 & 614.8 & 614.0 & 0.1 \\
\hline $10 \mathrm{H}-4$ & 86.95 & 0.24 & 0.5 & 37.5 & 556 & 597.1 & 603.3 & -0.5 \\
\hline $13 \mathrm{H}-4$ & 115.45 & 0.46 & 0.0 & 36.5 & 564 & 620.0 & 608.1 & 1.0 \\
\hline $16 \mathrm{H}-4$ & 143.95 & 0.57 & 0.1 & 37.0 & 569 & n.d. & 611.6 & n.d. \\
\hline $21 X-1$ & 187.35 & 0.57 & 0.2 & 36.5 & 567 & 601.0 & 609.6 & -0.7 \\
\hline $25 X-3$ & 229.15 & 0.39 & 13.7 & 37.5 & 574 & 609.2 & 613.4 & -0.3 \\
\hline \multicolumn{9}{|l|}{ 119-737B } \\
\hline $5 R-2$ & 256.45 & 0.22 & 52.3 & 37.5 & 574 & 608.6 & 612.4 & -0.3 \\
\hline $8 \mathrm{R}-2$ & 285.45 & 0.29 & 54.2 & 38.0 & 585 & 604.4 & 621.8 & -1.4 \\
\hline $11 R-2$ & 314.45 & 0.08 & 77.7 & 38.0 & 580 & 633.7 & 614.3 & 1.5 \\
\hline $14 \mathrm{R}-2$ & 347.80 & 0.12 & 47.7 & 38.5 & 579 & 620.6 & 612.6 & 0.7 \\
\hline $17 R-2$ & 372.30 & 0.11 & 32.9 & 39.0 & 589 & 626.3 & 612.8 & 1.1 \\
\hline $20 R-4$ & 404.30 & 0.05 & 6.3 & 39.5 & 581 & 639.2 & 614.8 & 2.0 \\
\hline 23R-1 & 428.80 & 0.00 & 18.3 & 39.0 & 577 & 646.9 & 608.5 & 3.1 \\
\hline $26 R-4$ & 462.30 & 0.01 & 52.2 & 39.0 & 577 & 633.4 & 609.1 & 2.0 \\
\hline $29 R-4$ & 491.30 & 0.04 & 22.3 & 38.5 & 576 & 603.2 & 608.8 & -0.5 \\
\hline $34 R-5$ & 541.00 & 0.07 & 28.2 & 39.0 & 579 & 606.8 & 613.9 & -0.6 \\
\hline $37 R-4$ & 568.40 & 0.00 & 16.9 & 39.5 & 586 & 608.8 & 618.1 & -0.8 \\
\hline $41 R-5$ & 608.50 & 0.01 & 39.8 & 39.5 & 582 & 617.3 & 614.1 & 0.3 \\
\hline \multicolumn{9}{|l|}{$119-738 \mathrm{~B}$} \\
\hline $1 \mathrm{H}-2$ & 2.95 & n.d. & n.d. & 35.5 & 556 & 613.3 & 610.6 & 0.2 \\
\hline $3 \mathrm{H}-5$ & 20.95 & 0.00 & 92.8 & 35.5 & 559 & 609.7 & 612.8 & -0.3 \\
\hline $7 \mathrm{H}-4$ & 57.45 & 0.00 & 95.4 & 36.0 & 560 & 632.5 & 608.4 & 1.9 \\
\hline $10 \mathrm{H}-2$ & 82.95 & 0.00 & 96.1 & 36.0 & 560 & 586.1 & 610.1 & -2.0 \\
\hline $13 \mathrm{H}-2$ & 106.95 & 0.00 & 95.0 & 36.0 & 562 & 585.6 & 612.1 & -2.2 \\
\hline $17 X-3$ & 141.65 & 0.00 & 96.7 & 36.0 & 562 & 596.4 & 612.5 & -1.3 \\
\hline $20 X-4$ & 172.15 & 0.00 & 97.2 & 36.0 & 568 & 597.0 & 618.4 & -1.8 \\
\hline $24 X-2$ & 207.55 & 0.00 & 94.2 & 36.5 & 568 & 597.7 & 617.3 & -1.6 \\
\hline
\end{tabular}

$20 \mathrm{H}-4$ contain $29 \%$ and $36 \%$ less sulfate, respectively, than their nearest-neighbor samples. This presents a dilemma.

Are these the actual in-situ sulfate concentrations of the interstitial waters, or are some of the samples contaminated with the surface seawater introduced during drilling? Contamination by seawater would tend to increase the concentration of sulfate in the samples. If contamination is the cause of the large-scale variation in the sulfate vs. depth profile, then 12 of the 14 samples have been affected. Assuming that the two samples with low sulfate concentrations are uncontaminated and that the sulfate concentration of the pore waters is a linear function of depth, then mixing with water that has a sulfate concentration of $28.9 \mathrm{mM}$ requires that the seawater component comprises $52 \%-77 \%$ of the remaining 12 samples. Due to the general absence of measurable phosphate and ammonium and the small amount of dissolved silica in seawater, this possibility has dras- tic implications for the concentration-vs.-depth profiles of these species in the interstitial waters at Site 736.

The concentrations of phosphate, silica, and ammonium do not indicate large-scale contamination of the interstitial waters with seawater. The two anomalous samples that have low sulfate concentrations do not show marked variations in their concentrations of other chemical species (Fig. 4). If the other 12 samples have been contaminated with seawater, they should have significantly lower concentrations of phosphate, ammonium, and silica. Instead, the four RCB samples show substantial increases in phosphate and silica relative to the XCB samples taken at a slightly higher level (Fig. 4). The RCB samples were taken from a different hole than the rest of the samples; thus, the phosphate increase may be real. However, the silica increase seen in the RCB samples is unrealistically large. A similar increase in dissolved silica was observed in the high-resolution 
Table 3 (continued).

\begin{tabular}{|c|c|c|c|c|c|c|c|c|}
\hline $\begin{array}{c}\text { Sample } \\
\text { (core, section) }\end{array}$ & $\begin{array}{l}\text { Depth } \\
\text { (mbsf) }\end{array}$ & $\begin{array}{l}\text { Organic carbon } \\
(\text { dry wt } \%)\end{array}$ & $\begin{array}{c}\mathrm{CaCO}_{3} \\
\text { (dry wt \%) }\end{array}$ & $\begin{array}{l}\text { Salinity } \\
(\mathrm{g} / \mathrm{kg})\end{array}$ & $\underset{(\mathrm{mM})}{\mathrm{Cl}^{-}}$ & $\begin{array}{l}\text { Cations } \\
\text { (meq/L) }\end{array}$ & $\begin{array}{l}\text { Anions } \\
\text { (meq/L) }\end{array}$ & $\begin{array}{c}\text { Charge imbalance } \\
(\%)\end{array}$ \\
\hline \multicolumn{9}{|l|}{$119-738 \mathrm{C}$} \\
\hline $4 \mathrm{R}-2$ & 218.85 & 0.01 & 83.2 & 36.5 & 567 & 599.0 & 617.1 & -1.5 \\
\hline $7 R-3$ & 247.70 & 0.07 & 91.0 & 36.5 & 565 & 582.4 & 614.1 & -2.6 \\
\hline 10R-2 & 276.70 & 0.02 & 69.6 & 36.0 & 568 & 598.2 & 615.7 & -1.4 \\
\hline $16 R-4$ & 337.50 & 0.13 & 87.6 & 36.5 & 572 & 594.9 & 619.7 & -2.0 \\
\hline $22 R-4$ & 395.50 & n.d. & 93.7 & 36.5 & 568 & 613.7 & 617.2 & -0.3 \\
\hline \multicolumn{9}{|l|}{$119-744 \mathrm{~A}$} \\
\hline $1 \mathrm{H}-2$ & 2.95 & n.d. & 58.4 & 35.5 & 548 & 627.2 & 608.4 & 1.5 \\
\hline $3 \mathrm{H}-3$ & 18.15 & n.d. & 1.1 & 35.0 & 546 & 605.8 & 605.9 & 0.0 \\
\hline $4 \mathrm{H}-2$ & 26.15 & n.d. & 79.9 & 36.0 & 555 & 618.5 & 616.1 & 0.2 \\
\hline $6 \mathrm{H}-3$ & 46.65 & n.d. & 96.2 & 35.8 & 556 & 616.8 & 613.9 & 0.2 \\
\hline $10 \mathrm{H}-3$ & 84.65 & n.d. & 88.3 & 35.8 & 558 & 622.4 & 615.5 & 0.6 \\
\hline $13 \mathrm{H}-4$ & 114.65 & n.d. & 80.6 & 36.2 & 560 & 620.0 & 619.5 & 0.0 \\
\hline $16 \mathrm{H}-4$ & 143.15 & n.d. & 63.3 & 36.0 & 558 & 609.5 & 611.7 & -0.2 \\
\hline $19 \mathrm{H}-4$ & 163.05 & n.d. & 93.8 & 36.5 & 560 & 616.2 & 619.6 & -0.3 \\
\hline \multicolumn{9}{|l|}{$119-744 \mathrm{~B}$} \\
\hline $2 \mathrm{H}-6$ & 18.39 & n.d. & 0.2 & 36.2 & 554 & 615.5 & 615.8 & 0.0 \\
\hline \multicolumn{9}{|l|}{$119-744 C$} \\
\hline $1 \mathrm{H}-1$ & 1.45 & n.d. & n.d. & 35.5 & 548 & n.d. & 609.1 & n.d. \\
\hline $1 \mathrm{H}-2$ & 2.95 & n.d. & 58.4 & 35.2 & 548 & n.d. & 606.2 & n.d. \\
\hline $1 \mathrm{H}-3$ & 4.45 & n.d. & n.d. & 35.5 & 548 & n.d. & 606.2 & n.d. \\
\hline $1 \mathrm{H}-4$ & 5.95 & n.d. & n.d. & 35.8 & 546 & n.d. & 602.8 & n.d. \\
\hline $1 \mathrm{H}-5$ & 6.90 & n.d. & n.d. & 35.2 & 557 & n.d. & 622.6 & n.d. \\
\hline $2 \mathrm{H}-4$ & 12.95 & n.d. & n.d. & 36.0 & 552 & n.d. & 611.8 & n.d. \\
\hline $3 \mathrm{H}-4$ & 22.45 & n.d. & n.d. & 36.0 & 556 & n.d. & 613.4 & n.d. \\
\hline $119-745 \mathrm{~A}$ & & & & & & & & \\
\hline $1 \mathrm{H}-5$ & 7.95 & 0.27 & 0.1 & 35.5 & 553 & 621.2 & 615.8 & 0.4 \\
\hline \multicolumn{9}{|l|}{$119-745 B$} \\
\hline $1 \mathrm{H}-2$ & 2.95 & 0.32 & 0.1 & 35.5 & 549 & 621.1 & 611.2 & 0.8 \\
\hline $3 \mathrm{H}-4$ & 20.45 & 0.43 & 0.1 & 36.2 & 555 & 624.0 & 616.9 & 0.6 \\
\hline $6 \mathrm{H}-4$ & 48.95 & 0.24 & 0.1 & 36.0 & 557 & 624.2 & 615.1 & 0.7 \\
\hline $9 \mathrm{H}-4$ & 77.45 & 0.19 & 0.1 & 35.5 & 558 & 609.8 & 614.3 & -0.4 \\
\hline $12 \mathrm{H}-4$ & 105.95 & 0.10 & 0.2 & 36.0 & 559 & 624.6 & 612.2 & 1.0 \\
\hline $14 \mathrm{H}-4$ & 124.95 & 0.13 & 0.1 & 35.8 & 555 & 604.6 & 605.4 & -0.1 \\
\hline $17 \mathrm{H}-4$ & 144.95 & 0.13 & 0.0 & 35.8 & 555 & 615.7 & 604.3 & 0.9 \\
\hline $19 \mathrm{H}-4$ & 163.95 & 0.16 & 0.1 & 35.2 & 555 & 607.2 & 603.6 & 0.3 \\
\hline $22 \mathrm{H}-4$ & 192.45 & 0.13 & 0.2 & 35.5 & 556 & 609.0 & 601.0 & 0.7 \\
\hline \multicolumn{9}{|l|}{$119-746 \mathrm{~A}$} \\
\hline $4 \mathrm{H}-4$ & 170.75 & 0.11 & 0.1 & 35.2 & 559 & 598.4 & 606.3 & -0.7 \\
\hline $7 \mathrm{H}-1$ & 194.75 & 0.09 & 0.1 & 35.5 & 559 & 606.2 & 603.3 & 0.2 \\
\hline $10 \mathrm{H}-4$ & 223.75 & 0.16 & 0.1 & 35.8 & 562 & 599.4 & 601.5 & -0.2 \\
\hline $13 \times-4$ & 248.15 & 0.12 & 4.6 & 35.5 & 561 & 594.8 & 599.7 & -0.4 \\
\hline
\end{tabular}

samples (Cranston, this volume) and may be due to the disruption of silica tests during the rotary drilling process. Breakage of the diatom tests would expose fresh surfaces with an attendant increase in the solubility of the silica. Ammonium concentrations increase with depth in a smooth diffusion profile, but level off and remain essentially constant in the XCB and RCB samples (Fig. 4). None of the concentration-vs.-depth profiles of these chemical species indicate the large-scale contamination that the sulfate profile alludes to, but the chemistry of the interstitial-water samples has clearly been affected by the drilling processes employed at Site 736.

None of the other chemical species measured in the pore waters display variations that correlate with changes in coring procedures. The concentrations of dissolved magnesium, calcium, sodium, potassium, and chloride do not vary substantially from seawater concentrations with increasing depth.
Despite the ambiguous quality of the pore water samples retrieved at Site 736 , several points can be made concerning the chemical environment of the sedimentary reservoir. An adequate supply of reactable organic matter has been supplied to and retained by the sediments to allow the onset of anaerobic sulfate reduction. The increase in ammonium concentration with depth indicates that this catabolic process is active to a depth of at least 180 mbsf. Dissolution of the great abundance of biogenic silica in the sediments is responsible for aqueous silica concentrations an order of magnitude greater than that of seawater. The volcanic debris in lithologic Unit $\mathrm{I}$ is not reacting with the interstitial waters or the water-to-rock ratio is too high for these reactions to affect the composition of the waters. And last, but not least, Site 736 provides an excellent example of how difficult it can be to ascertain the effects of drilling on the chemistry of interstitial waters without the benefit of in-situ sampling. 

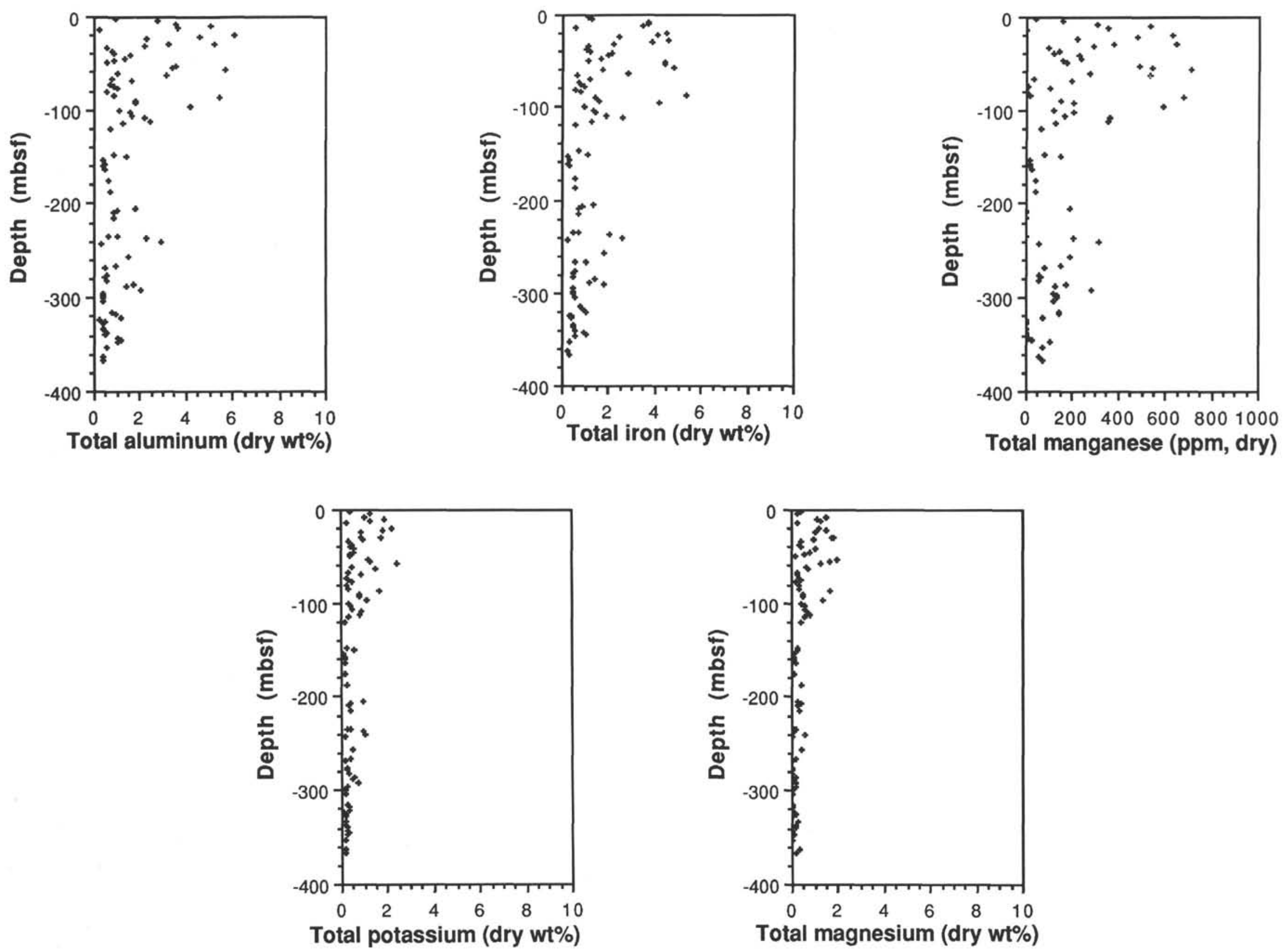

Figure 2. Metal contents of Site 736 sediments using data from Cranston (this volume). 

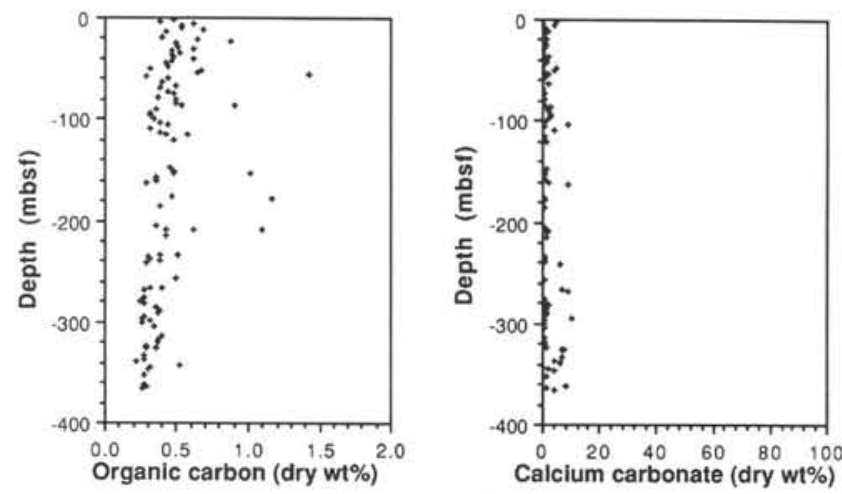

Figure 3. Organic carbon and calcium carbonate contents of Site 736 sediments. Plots incorporate data collected from ODP minicore samples (Table 3) and high-resolution samples (Cranston, this volume).

\section{Site 737}

\section{Sediment Characteristics}

A diverse middle Eocene to Quaternary sedimentary section was recovered at Site 737. Leg 119 sedimentologists devised a lithologic classification that consists of six units (Table 4). Underneath the $1.5 \mathrm{~m}$ layer of sand that represents the seafloor, the sedimentary record at Site 737 picks up where the lowermost strata at Site 736 left off in the upper Pliocene. The rapidly deposited Unit II is separated from Unit III by a 10-8.2 Ma hiatus (Barron, Larsen, et al., 1989). The near total lack of calcium carbonate in the uppermost $200 \mathrm{~m}$ of the section can be clearly seen in Figure 5. As this site is well above the regional carbonate compensation depth (CCD), the large decrease in calcium carbonate content represents a transition from calcareous to siliceous sedimentation that is probably related to the northward movement of the Antarctic Convergence to the paleolatitude of Site 737. Unit IV caps a 6-8 m.y. hiatus that extends into the late Oligocene (Barron, Larsen, et al., 1989). Units V and VI comprise the bulk of the cored section (Table 4). Volcanic debris was observed in minor amounts throughout the section but was found to be present in large quantities locally. Ash layers were discovered in Unit II, and volcanic glass with variable degrees of alteration comprised approximately $10 \%-30 \%$ of Unit V from 330.8 to 417.7 mbsf (Barron, Larsen, et al., 1989; Morche et al., this volume). "Detrital particles" were discovered only in trace quantities, but the origin of large quantities of clay minerals in the Unit VI limestone was not indicated by the shipboard scientists. Organic carbon contents decrease from about $0.5 \%$ near the seafloor to values approaching zero below $300 \mathrm{mbsf}$ $($ mean $=0.3 \%, \mathrm{n}=123$, s.d. $=0.18$; Fig. 5$)$.

Many diagenetic features that may provide clues as to the forces responsible for the present distribution of pore-water solutes were readily apparent during shipboard observations. Carbonate diagenesis becomes more advanced with increasing depth. The downhole nannofossil ooze to chalk (claystone) to limestone transitions are the most obvious diagenetic features observed at Site 737. Micrite concretions were noted at the shallow depth of 67.5 mbsf (Barron, Larsen, et al., 1989). Much of the carbonate in Units V and VI is micritic calcite. The majority of the section is heavily bioturbated as a consequence of the persistence of well-oxygenated depositional environments (Droser and Bottjer, this volume). A deep green "diagenetic color banding" commonly overprints the burrow structures in Units V and VI (Barron, Larsen, et al., 1989; Droser and Bottjer, this volume). It is speculated that this banding is due to shifts in the vertical position of early diagenetic, oxidation-reduction boundaries (Barron, Larsen, et al., 1989; Droser and Bottjer, this vol- ume). Units V and VI are barren of siliceous microfossils, but small layers of diagenetic silica (opal-CT or microcrystalline quartz) occur in both units. The high temperature gradient measured at Site 737 indicates that the temperature at the bottom of Hole $737 \mathrm{~B}$ was approximately $70^{\circ} \mathrm{C}$. Studies by Murata and Larson (1975), Murata et al. (1977), Keller and Isaacs (1985), and Williams et al. (1985) suggest that, given the abundance of biogenic silica high in the sedimentary section and the relatively high temperatures, the bottom levels of Hole 737B may represent active sites of silica diagenesis. Small pyrite grains, sparry calcite, and glauconitic overgrowths were also noted in Units V and VI (Barron, Larsen, et al., 1989).

\section{Interstitial-Water Chemistry}

Interstitial waters were sampled to a total depth of 608.5 mbsf at Site 737 . Twenty samples were obtained by routine ODP procedures and 103 samples by means of the high-resolution technique. Deeper sampling of the pore fluids was precluded by the low water content of the claystones (approximately 15\%) and limestones (approximately 10\%-20\%) of Units V and VI (Barron, Larsen, et al., 1989). Time restrictions prevented the sampling of the deeper levels of Hole 737B with the high-resolution technique. In contrast to Site 736 , interstitial-water sample integrity was rather good at Site 737 and no obvious signs of contamination were observed. The high bottom of hole temperature (approximately $70^{\circ} \mathrm{C}$ ), however, indicates that the temperature effects on the composition of the pore-fluid samples may have been significant.

In sharp contrast to Site 736 , the interstitial-water solute distributions at Site 737 show marked variations with increasing depth (Fig. 6). The total concentration of solutes (salinity) and the chloride concentration are both positively correlated with depth ( $r=0.903$ and $r=0.832$, respectively; $n=20$ for both), suggesting that there has been a net release of ions to the interstitial waters and/or that the fluids have experienced a net loss of water due to the precipitation of hydrous minerals. Alkalinity $(r=-0.872)$, sulfate $(r=-0.855)$, sodium $(r=-0.955)$, potassium $(r=-0.974)$, and magnesium $(r=-0.929)$ concentrations are negatively correlated with depth, whereas $\mathrm{pH}(\mathrm{r}=$ $0.841)$ and calcium concentrations $(r=0.982)$ are positively correlated with depth.

Reactions involving the sediments and interstitial waters have had an effect upon nearly all of the chemical parameters that we measured. For the sake of discussion, the processes affecting the vertical distribution of solutes at Site 737 can be separated into those that are related to the catabolism of organic matter trapped within the sediments and those that result in the dissolution, precipitation, or recrystallization of solid silicates. In reality, many solutes are involved in both organic and inorganic reactions.

Biogeochemical Processes. During the consumption of organic matter by bacteria in marine sediments, oxidants are removed from, and several byproducts that are rare in seawater are released to, their surrounding interstitial waters. In the Site 736 discussion, we listed the most commonly used oxidants. The order in which they are removed from pore waters is a function of their relative reduction potentials. Due to their abundances in seawater, dissolved oxygen and sulfate accept most of the electrons removed from organic carbon trapped in marine sediments during its transformation into less saturated forms. The net reactions for catabolic processes involving organic matter, molecular oxygen, and sulfate are:

Aerobic respiration

$$
\begin{aligned}
& \left(\mathrm{CH}_{2} \mathrm{O}\right)_{106}\left(\mathrm{NH}_{3}\right)_{16} \mathrm{H}_{3} \mathrm{PO}_{4}+138 \mathrm{O}_{2}+108 \mathrm{H}_{2} \mathrm{O}- \\
& 106 \mathrm{HCO}_{3}^{-}+16 \mathrm{NO}_{3}^{-}+\mathrm{HPO}_{4}^{2-}+124 \mathrm{H}_{3} \mathrm{O}^{+}
\end{aligned}
$$



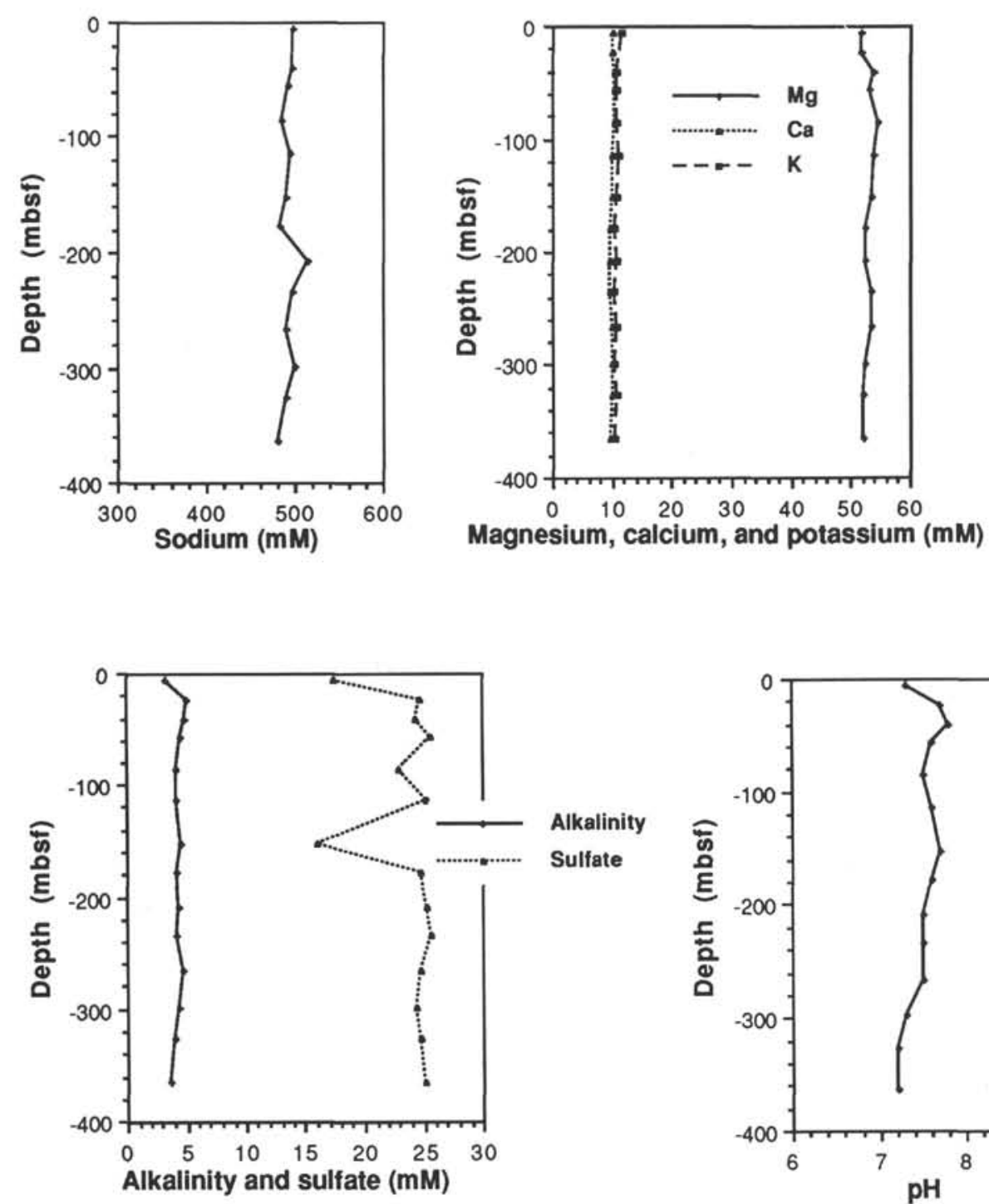

Figure 4. Interstitial water solute distributions at Site 736.
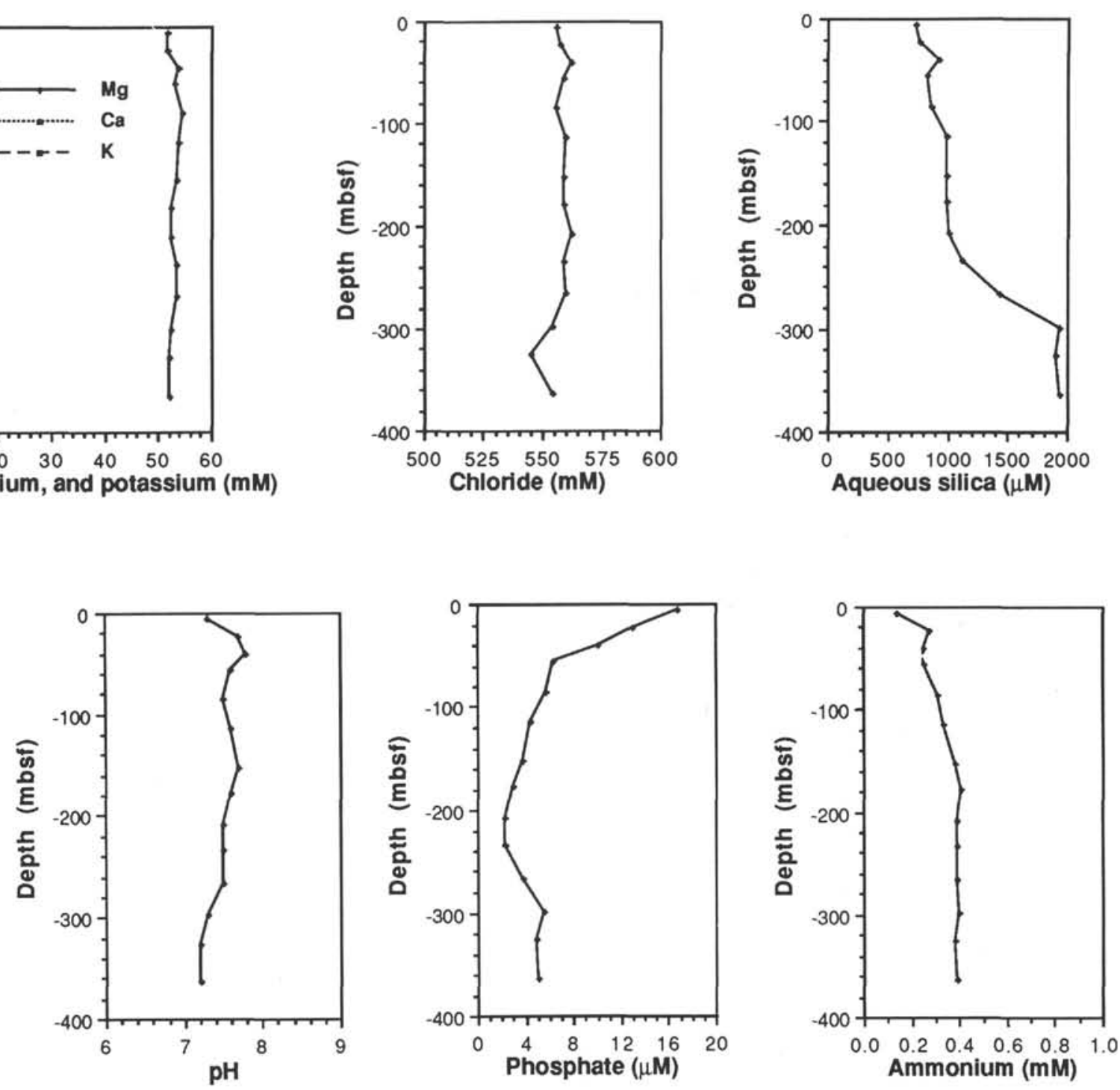
Table 4. Lithology summary for Site 737 from Barron, Larsen, et al. (1989).

\begin{tabular}{|c|c|c|c|}
\hline Epoch & Unit & $\begin{array}{l}\text { Depth } \\
\text { (mbsf) }\end{array}$ & Lithology \\
\hline Quaternary & I & $0-1.5$ & $\begin{array}{l}\text { Mixed glauconitic sand and } \\
\text { diatom ooze }\end{array}$ \\
\hline $\begin{array}{l}\text { lower Pliocene- } \\
\text { upper Miocene }\end{array}$ & II & $1.5-240.1$ & Diatom ooze \\
\hline $\begin{array}{l}\text { upper Miocene- } \\
\text { middle Miocene }\end{array}$ & III & 240.1-306.6 & $\begin{array}{l}\text { Diatom calcareous nannofos- } \\
\text { sil ooze }\end{array}$ \\
\hline middle Miocene & IV & $306.6-321.1$ & $\begin{array}{l}\text { Sandy siltstone and calcareous } \\
\text { nannofossil ooze with } \\
\text { volcanic sand }\end{array}$ \\
\hline $\begin{array}{l}\text { upper Oligocene- } \\
\text { middle Eocene }\end{array}$ & V & $321.1-677.9$ & $\begin{array}{l}\text { Calcareous claystone inter- } \\
\text { stratified with volcanic } \\
\text { sand }\end{array}$ \\
\hline middle Eocene & V1 & $677.9-711.2$ & Clayey limestone \\
\hline
\end{tabular}
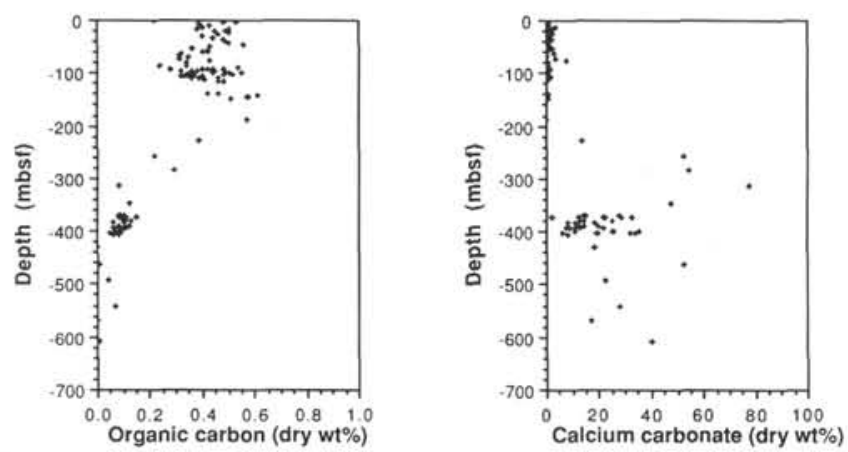

Figure 5. Organic carbon and calcium carbonate contents of Site 737 sediments. Plots incorporate data collected from ODP minicore samples (Table 3 ) and high-resolution samples (Cranston, this volume).

\section{Sulfate reduction}

$$
\begin{aligned}
& \left(\mathrm{CH}_{2} \mathrm{O}\right)_{106}\left(\mathrm{NH}_{3}\right)_{16} \mathrm{H}_{3} \mathrm{PO}_{4}+53 \mathrm{SO}_{4}^{2-}+39 \mathrm{H}_{2} \mathrm{O}- \\
& 106 \mathrm{HCO}_{3}^{-}+53 \mathrm{HS}^{-}+16 \mathrm{NH}_{4}^{+}+\mathrm{HPO}_{4}^{2-} \\
& +39 \mathrm{H}_{3} \mathrm{O}^{+}
\end{aligned}
$$

It should be noted that sulfate reduction is a strictly anoxic process. As the reactions imply, essentially all of the sulfide, phosphate, and ammonium in interstitial waters of marine sediments can be accounted for in these biochemical reactions. The carbon dioxide, sulfide, and phosphate released by bacteria also contribute to the total alkalinity of the pore waters. The degree of oxidant removal and byproduct formation is ultimately limited by the supply of reactable organic matter to the sediments.

The vertical distributions of particulate organic carbon and dissolved sulfate, phosphate, ammonium, and alkalinity in the interstitial waters indicate that sulfate reduction is the major biochemical process consuming organic matter at Site 737. As we mentioned previously, the organic carbon content of the sediments is low and essentially disappears below 300 mbsf. Dissolved sulfate decreases approximately $39 \%$ from 3 to $348 \mathrm{mbsf}$, drops off abruptly in a minimum centered near $372 \mathrm{mbsf}$, and remains at the 348 mbsf concentration to 608 mbsf (Fig. 6). As Figure 7 shows, the sharp minimum is corroborated by the highresolution study, which pinpoints the minimum at $393 \mathrm{mbsf}$. It also shows that the minimum is associated with a significant drop in the reduction potential of the samples, suggesting that the minimum is real and that it may represent a reaction zone in the sediment column. The pyrite found in Unit V may be the ultimate sink of the sulfide produced at this depth (Barron, Lar- sen, et al., 1989). Phosphate was detectable only in the shallowest samples (Fig. 6). Ammonium increases with depth until a maximum of $0.33 \mathrm{mM}$ is reached at approximately $256 \mathrm{mbsf}$ and decreases with depth to 608 mbsf (Fig. 6). The alkalinity of the pore waters never rises significantly above its concentration in seawater and, instead, decreases with depth by a factor of $86 \%$ at 314 mbsf (Fig. 6). Alkalinity remains essentially constant between 314 and 608 mbsf $($ mean $=0.38 \mathrm{mM}$, s.d. $=$ $0.10, \mathrm{n}=9$ ).

The amount of reactable organic matter is clearly limiting the amount of sulfate reduction at Site 737. The organic carbon content of the minicore samples is positively correlated with the dissolved sulfate concentration of the interstitial waters squeezed from them $(r=0.793, n=20)$. The low phosphate and ammonium concentrations confirm the low intensity of microbial sulfate reduction at Site 737 and support the conclusion that the availability of reactable organic matter is the limiting factor.

Precipitation of solid carbonates is the most likely process causing the depletion of pore-water alkalinity with increasing depth. The saturation state of calcium carbonate is predominantly a function of the concentrations of dissolved carbonate and calcium ions and the ambient temperature. The solubility of calcium carbonate decreases with increasing temperature. Even at the low alkalinities encountered at Site 737, high concentrations of calcium ions can create a saturated or supersaturated condition. At Site 737, we measured some of the highest dissolved calcium concentrations (up to $141.5 \mathrm{mM}$ ) ever encountered in pelagic marine sediments. Figure 8 displays the correlations between alkalinity and dissolved sulfate and calcium. The strong correlations between these three parameters support the conclusions that alkalinity production is linked to sulfate reduction and that alkalinity loss is tied to the release of large quantities of calcium ions to the interstitial waters. The downhole transitions from carbonate oozes to chalks to limestones provide physical evidence that the combination of a high temperature gradient and high dissolved calcium concentrations creates an ideal environment for calcium carbonate precipitation in the lower reaches of Hole 737B.

Inorganic Processes. All of the major cations in the interstitial waters of Site 737 are strongly correlated with depth below the seafloor. The most conspicuous downhole trend is the $1130 \%$ increase in dissolved calcium (Table 1). Charge balance is maintained by large decreases in the concentrations of sodium $(31 \%)$, magnesium $(97 \%)$, and potassium $(90 \%)$. The linear correlations are, however, much stronger in the upper $372 \mathrm{mbsf}$ than they are over the entire sampling interval. Figure 9 clearly shows that dissolved calcium, magnesium, and potassium have nearly perfect linear correlations from 0 to $372 \mathrm{mbsf}$, and that these correlations fall apart between 404 and 608 mbsf. While they are still detectable, dissolved magnesium and potassium have essentially disappeared from the interstitial waters below 372 mbsf. The dissolved calcium concentration continues to increase below this depth but markedly deviates from its depth gradient in the uppermost 372 mbsf.

Their linear correlations suggest that the major cation distributions are controlled by diffusive processes between 0 and 372 mbsf at Site 737. Chemical gradients in sediment pore fluids are the result of compositional differences between reservoirs with which they communicate. Because they connect all of the major components of the uppermost crust (seismic Layer 1) and offer little resistance to chemical diffusion, pore fluids are the major conduits for the transport of ions between crustal reservoirs. Molecular diffusion and convection are the most important transport processes operating to remove the chemical potential gradients produced by water-sediment and water-basement rock interactions. In open-ocean regions where there is a thick sediment cover upon the basaltic basement, convective fluid trans- 

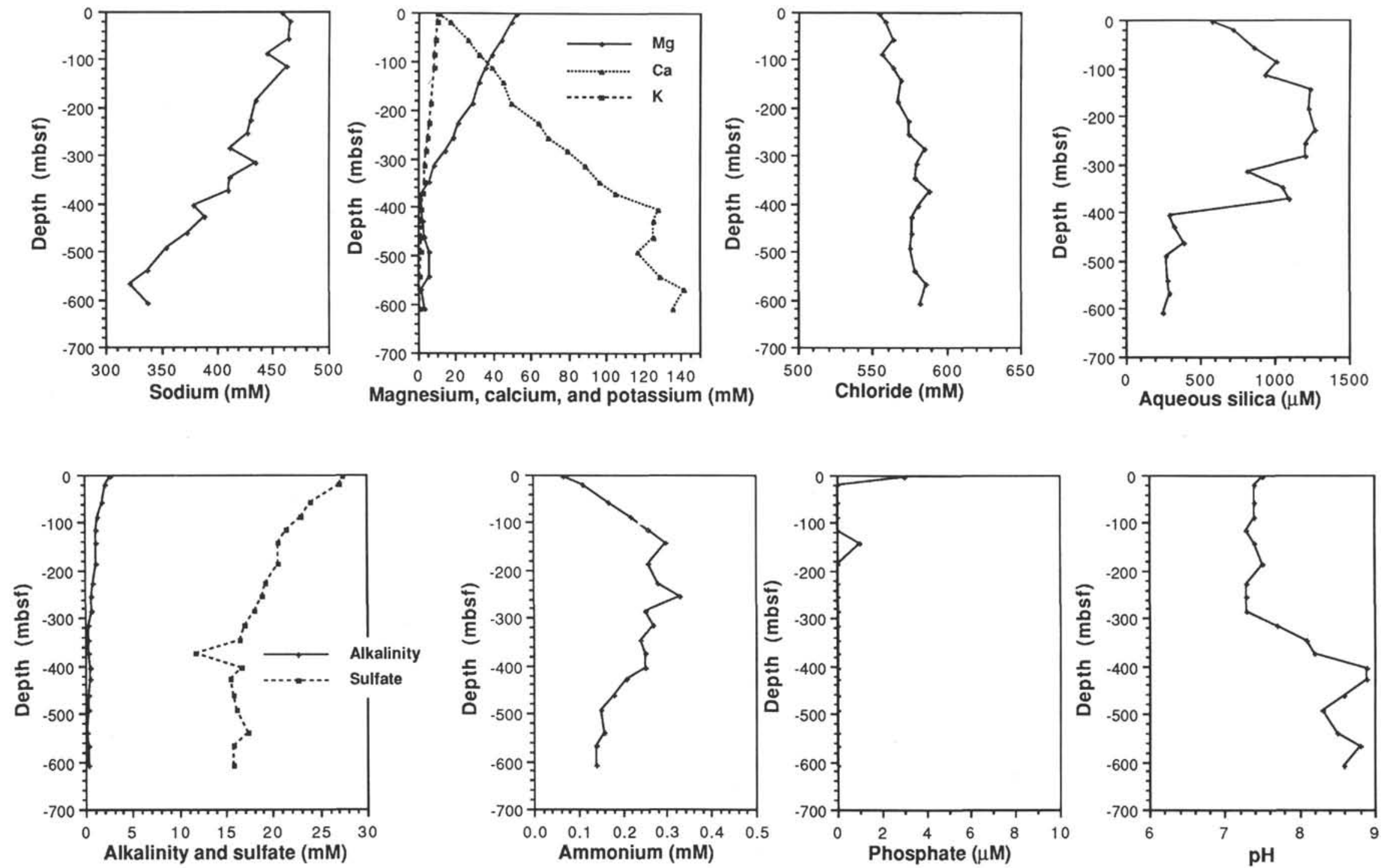

Figure 6. Interstitial water solute distributions at Site 737. 

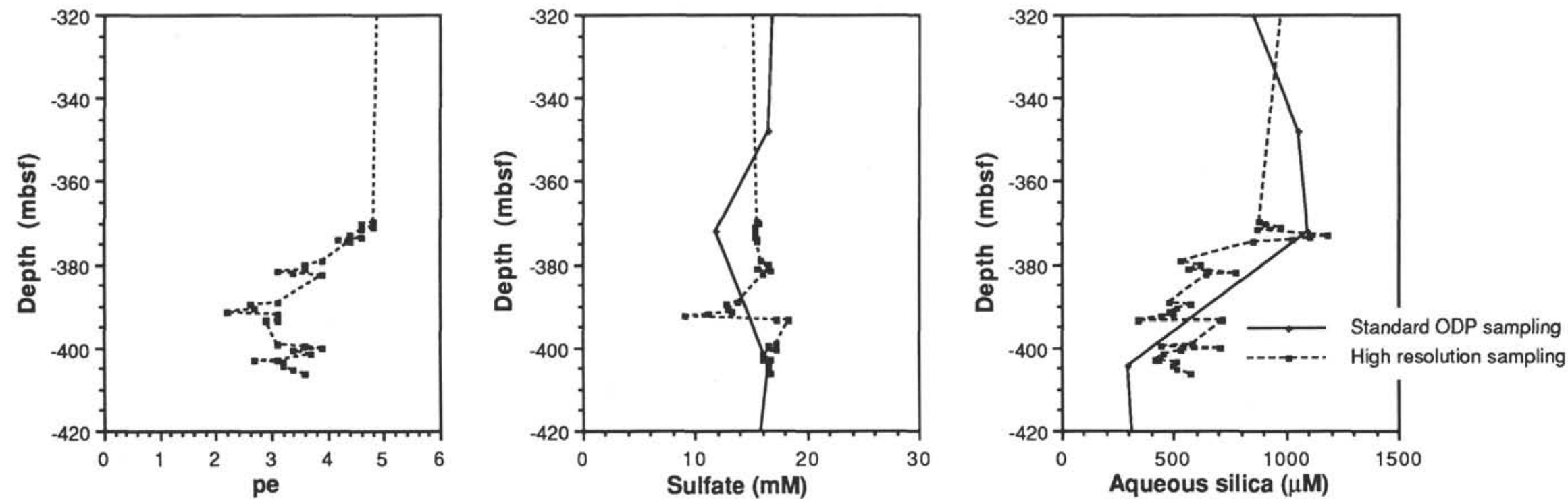

Figure 7. Expanded view of chemical shifts occurring between 320 and $420 \mathrm{mbsf}$ at Site 737 . Note the sharp decreases in oxidation-reduction potential, dissolved sulfate, and aqueous silica that occur between $370 \mathrm{mbsf}$ and $400 \mathrm{mbsf}$. Dashed lines connect data from Cranston (this volume). Solid lines connect data obtained from ODP minicore samples. 


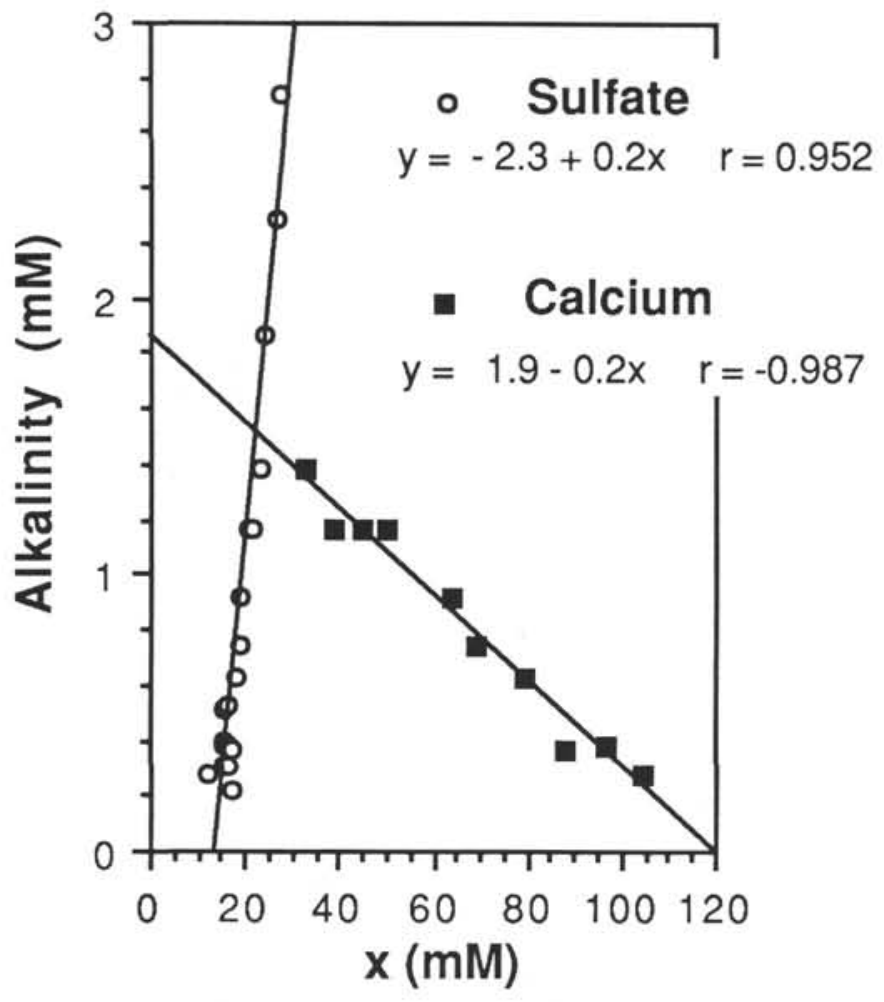

Figure 8. Interstitial water alkalinity, sulfate, and calcium correlations for Site 737, 0-372 mbsf. Solid lines represent linear least-square regressions through the chemical data. Equations and correlation coefficients for each line are also shown.

port of heat from deeper levels of the crust ceases. This is due to severe porosity reduction in the heavily compacted lower layers of the sediment column. Numerical modeling of chemical gradients in Deep Sea Drilling Project (DSDP) holes has shown that linear correlations between major dissolved cations are a result of their conservative behavior (McDuff and Gieskes, 1976; McDuff, 1978, 1981). Chemical reactions between sediments and their pore waters generally result in abrupt shifts in the solute gradients. Linear concentration vs. depth gradients are, therefore, indications of diffusive transport between reservoirs with different chemical compositions.

The fluxes of calcium, magnesium, sodium, and potassium between the seafloor and 372 mbsf can be estimated by means of the Fick's law relationship:

$$
\mathbf{J}=-\mathrm{D}_{\mathrm{i}}\left(\partial \mathrm{C}_{\mathrm{i}} / \partial \mathrm{z}\right)
$$

where $J$ is the flux $\left(\mathrm{g} / \mathrm{cm}^{2} / \mathrm{s}\right), D_{i}$ is the bulk sediment diffusion coefficient of solute $i\left(\mathrm{~cm}^{2} / \mathrm{s}^{1}\right), C_{i}$ is the concentration of species $\mathrm{i}$ in the interstitial water $\left(\mathrm{g} / \mathrm{cm}^{3}\right)$, and $\mathrm{z}$ is the distance in centimeters below the seafloor (positive downward). The major cation fluxes for Site 737 are shown in Table 5. Advection of pore water due to compaction is ignored in these calculations. The assumption of constant diffusion coefficients with depth can be partially justified by the linear nature of the concentration-vs.depth trends in the upper $372 \mathrm{mbsf}$ at Site 737 . Variations in diffusion coefficients due to changes in porosity and temperature, as a function of depth, would have the effect of curving the solute gradients. The diffusion coefficients used here are not based on resistivity measurements of Site 737 sediments, but they represent best estimates based upon the available literature (Gieskes and Lawrence, 1981; Sayles, 1981). The calculations indicate

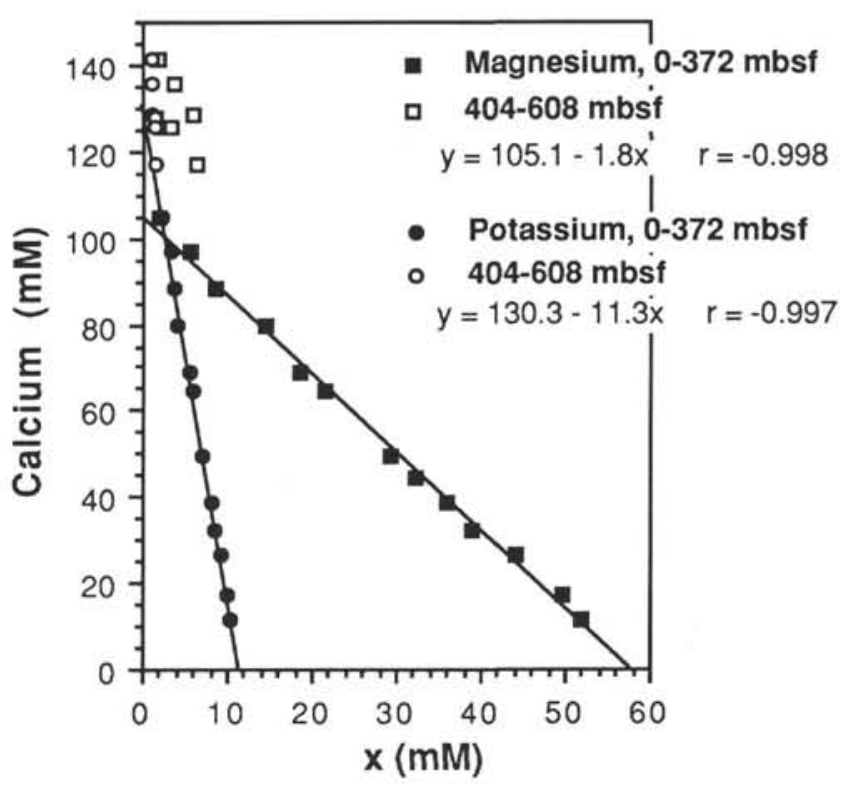

Figure 9. Major cation correlations for Site 737 interstitial waters. Solid lines represent linear least-square regressions through the chemical data collected from samples taken between the sea floor and $372 \mathrm{mbsf}$. Equations and correlation coefficients for each line are also shown. Note how the data from samples below 372 mbsf deviate from the linear regression-lines.

Table 5. Concentration-vs.-depth gradients, diffusion coefficients, and fluxes of major cations in Kerguelen Plateau interstitial waters.

\begin{tabular}{|c|c|c|c|c|}
\hline Sites & 737 & 738 & 744 & 745 and 746 \\
\hline $\begin{array}{l}\partial[\mathrm{Na}] / \partial \mathrm{z} \\
(\mathrm{mM} / 1100 \mathrm{~m})\end{array}$ & -14.6 & 0.0 & 0.0 & 0.0 \\
\hline $\begin{array}{l}\partial[\mathrm{Mg}] / \partial \mathrm{z} \\
(\mathrm{mM} / 100 \mathrm{~m})\end{array}$ & -13.4 & -4.0 & -3.1 & -8.6 \\
\hline $\begin{array}{l}\partial[\mathrm{Ca}] / \partial \mathrm{z} \\
(\mathrm{mM} / 100 \mathrm{~m})\end{array}$ & 24.4 & 5.1 & 4.1 & 4.6 \\
\hline $\begin{array}{l}\partial[\mathrm{K}] / \partial \mathrm{z} \\
(\mathrm{mM} / 100 \mathrm{~m})\end{array}$ & -2.2 & -1.0 & -0.5 & -1.4 \\
\hline $\begin{array}{l}\mathrm{D}_{\mathrm{Na}} \\
\left(10^{-6} \mathrm{~cm}^{2} / \mathrm{s}\right)\end{array}$ & 3.00 & 1.50 & 1.50 & 3.00 \\
\hline $\begin{array}{l}\mathrm{D}_{\mathrm{Mg}} \\
\left(10^{-6} \mathrm{~cm}^{2} / \mathrm{s}\right)\end{array}$ & 2.00 & 1.00 & 1.00 & 2.00 \\
\hline $\begin{array}{l}\mathrm{D}_{\mathrm{Ca}} \\
\left(10^{-6} \mathrm{~cm}^{2} / \mathrm{s}\right)\end{array}$ & 2.00 & 1.00 & 1.00 & 2.00 \\
\hline $\begin{array}{l}\mathrm{D}_{\mathrm{K}} \\
\left(10^{-6} \mathrm{~cm}^{2} / \mathrm{s}\right)\end{array}$ & 5.00 & 2.50 & 2.50 & 5.00 \\
\hline $\begin{array}{l}\mathrm{J}_{\mathrm{Na}} \\
\left(10^{-3} \mathrm{~mol} / \mathrm{cm}^{2} \mathrm{~m} . \mathrm{y}_{\mathrm{y}}\right)\end{array}$ & 138 & 0 & 0 & 0 \\
\hline $\begin{array}{l}\mathrm{J}_{\mathrm{Mg}} \\
\left(10^{-3} \mathrm{~mol} / \mathrm{cm}^{2} \mathrm{~m} . \mathrm{y} .\right)\end{array}$ & 84 & 13 & 10 & 54 \\
\hline $\begin{array}{l}{ }_{\mathrm{Ca}} \\
\left(10^{-3} \mathrm{~mol} / \mathrm{cm}^{2} \mathrm{~m} . \mathrm{y}_{\mathrm{y}}\right)\end{array}$ & -154 & -16 & -13 & -29 \\
\hline $\begin{array}{l}\mathrm{J}_{\mathrm{K}} \\
\left(10^{-3} \mathrm{~mol} / \mathrm{cm}^{2} \mathrm{~m} . \mathrm{y} .\right)\end{array}$ & 34 & 8 & 4 & 22 \\
\hline
\end{tabular}

that there is a substantial flux of calcium ions from the lower sediment layers to the seafloor. This is balanced by fluxes of magnesium, potassium, and sodium into the sediments. The fact that the total downward flux of charge equivalents is not exactly balanced by the upward flux indicates that either the diffusion coefficients chosen are not entirely appropriate for this site or that some of the cation fluxes are coupled with the diffusion of anions. They do, however, provide a relative measure of flux magnitudes between the ocean and sediments on the NKP. 
Changes in the vertical concentration gradients of dissolved calcium, magnesium, and potassium indicate that a reaction zone is present near 380 mbsf at Site 737 . The fact that the concentrations of magnesium and potassium fall to values close to zero nearly $1 \mathrm{~km}$ above the basaltic basement indicates that they are being consumed within the sediment column and not through the hydrolysis of basement rocks. Alteration of the large amount of volcanic glass noted by the shipboard sedimentologists between 331 and 418 mbsf is a likely sink for these cations. Studies of DSDP sites with abundant volcanic debris have shown that these alteration reactions can result in large calcium, magnesium, and potassium concentration gradients (Gieskes and Lawrence, 1981). The dissolved sodium gradient does not deviate as greatly as those of magnesium and potassium at $\mathbf{3 7 2} \mathrm{mbsf}$, and the concentration of calcium continues to rise erratically below this depth. It is likely that sodium and calcium are also involved in basement-rock alteration processes at deeper levels. Investigations of DSDP sites where major cation gradients are largely diffusion controlled indicate that, in regions of high calcium fluxes, magnesium fluxes become diffusion limited and sodiumbearing alteration phases predominate (McDuff, 1981). Assuming that $1 \mathrm{~km}$ of sediment, with a bulk-density of $2.4 \mathrm{~g} / \mathrm{cm}^{3}$ and a porosity of $20 \%$, separates the reaction zone from the basement at Site 737 , the fluxes of magnesium and potassium into these sediments would change their composition by only $0.03 \%$ and $0.02 \%$, respectively, during a $30 \mathrm{~m} . \mathrm{y}$. period. This small amount would be, and is, difficult to identify.

The vertical distribution of aqueous silica at Site 737 is controlled by reactions between the interstitial waters and their surrounding sediments. Diatomaceous sediments are abundant to a depth of $307 \mathrm{mbsf}$ at this site. Aqueous silica concentrations are well above those of surface seawater near the sediment/water interface, indicating that there is a net flux of silica out of the sediments. The source of this dissolved silica is the dissolution of siliceous microfossils in the uppermost portion of the sediment column. The concentration-vs.-depth profile of this chemical species (Fig. 6) displays a strong maximum centered near 230 mbsf. Given that the in-situ temperature at $230 \mathrm{mbsf}$ is similar to room temperature, the thermal effect on the aqueous silica concentration of the samples taken near this depth should have been minimal. The concentration of aqueous silica near the maximum $(1260 \mu \mathrm{M})$ is within the range of amorphous silica solubilities and well above the solubilities of cristobalite and quartz at $25^{\circ} \mathrm{C}$ reported by Alexander (1957), Walther and Helgeson (1977), and Iler (1979). Concentrations drop $73 \%$ between 372 and 404 mbsf (Table 2). Figure 8 shows that the large depletion in aqueous silica has been pinpointed at $377 \mathrm{mbsf}$ by the high-resolution technique (Cranston, this volume). Clearly, silica is dissolving from the sediments in the uppermost $300 \mathrm{~m}$ of the sediment column, diffusing upward to the ocean bottom waters, and precipitating in an unknown form near $377 \mathrm{mbsf}$.

All of the chemical analyses conducted on samples from Site 737 point to a diagenetic front moving up through the sediment column. Changes in the gradients of calcium, magnesium, and potassium and the sharp drop in aqueous silica between 370 and $400 \mathrm{mbsf}$ indicate that authigenic silicates and diagenetic silica phases may be precipitating there. The precipitation of silica phases is supported by the presence of silica-filled foraminifer tests, silica spherules, and "chert" beds in Units V and VI (Barron, Larsen, et al., 1989). Magnesium and potassium are probably being used up in the alteration of volcanic debris. Calcium is being released during the alteration of volcanic debris and basaltic basement rocks. Sodium silicates are likely precipitates at deeper, unsampled levels of the sediment column. This silicification front coincides with a sharp drop in electrode potential (pe), a sulfate minimum, and a sharp $\mathrm{pH}$ rise. In addition, physical-properties and logging specialists measured sharp rises in resistivity and sonic velocity that suggest an abrupt increase in lithification and loss of porosity due to compaction and/or cementation of the sediments (Barron, Larsen, et al., 1989). A plausible explanation for these physical and chemical anomalies is the upward movement of a diagenetic front that is depositing authigenic silicates, diagenetic silica, and calcium carbonate. These reactions would result in reductions in porosity and permeability that would partially cut off diffusive communication with the lower sediment layers and move the focus of sulfate reduction upward. The rise in $\mathrm{pH}$ indicates that the hydrolysis of volcanic debris and basaltic basement rocks, and the associated release of calcium ions exceeds the precipitation of authigenic silicates and calcium carbonate. Thus, the main contribution of the diagenetic chemical reactions to porosity reduction may be the breakdown of the sediment framework and subsequent compaction (cf. Isaacs, 1981).

\section{Southern Kerguelen Plateau (Sites 738 and 744)}

Sites $738\left(62^{\circ} 42.54^{\prime} \mathrm{S}, 82^{\circ} 47.25^{\prime} \mathrm{S}\right)$ and $744\left(61^{\circ} 34.6^{\prime} \mathrm{S}\right.$, $\left.80^{\circ} 35.46^{\prime} \mathrm{E}\right)$ are located on the southernmost extension of the Kerguelen Plateau, approximately $1600 \mathrm{~km}$ southeast of Kerguelen Island and the NKP sites (Fig. 1B). They are positioned north of the Antarctic Divergence, beneath the Antarctic Circumpolar Current, and within the Antarctic Circumpolar Deep Water. The water depths are $2252.5 \mathrm{~m}$ and $2307.3 \mathrm{~m}$ at Sites 738 and 744 , respectively.

The SKP sites are effectively isolated from emergent sediment sources to the north (Kerguelen and Heard islands) and to the south (Antarctica). Approximately $662 \mathrm{~m}$ of relatively pure pelagic sediments was recovered at these sites during Leg 119. The sediments are early Turonian to Quaternary in age. Coring operations penetrated the entire sedimentary section at Site 738 , and $38 \mathrm{~m}$ of basaltic basement rock was retrieved. Petrologic studies of the basalt indicate that it was deposited above sea level or in very shallow water (Barron, Larsen, et al., 1989). The region has subsequently subsided to its present depth. Low average sediment-accumulation rates $(2-4.6 \mathrm{~m} / \mathrm{m}$.y.) and numerous hiatuses indicate that the SKP is a region characterized by sporadic sediment accumulation (Barron, Larsen, et al., 1989).

Temperature measurements at Site 744 indicate that the thermal gradient of the SKP is approximately $50 \%$ lower than that of the NKP. The seafloor temperature was $1^{\circ} \mathrm{C}$ at Site 744 (Barron, Larsen, et al., 1989). Additional measurements below the seafloor yielded a thermal gradient of $43^{\circ} \mathrm{C} / \mathrm{km}$ (Barron, Larsen, et al., 1989). The relatively low SKP thermal gradient is at least partially due to its thinner, less insulating cover of sediment.

\section{Site 738}

\section{Sediment Characteristics}

Unlike the predominantly biosiliceous sediments recovered to the north, the sedimentary section cored at Site 738 reveals more than 80 m.y. of mostly carbonate accumulation. Leg 119 sedimentologists devised a lithologic classification for Site 738 that consists of eight units (Table 6). The entire Neogene period is represented by a mere $17.7 \mathrm{~m}$ of diatom ooze that grades into calcareous nannofossil ooze. Most of the Oligocene and Miocene record is missing. Preceding the final, short gasp of siliceous sedimentation is nearly $480 \mathrm{~m}$ of lower Turonian to lower Oligocene calcareous sediment in various stages of diagenetic transformation. Nannofossil oozes give way to chalks near 205 mbsf, and the chalks grade into limestones below 428 mbsf (Barron, Larsen, et al., 1989). Biogenic silica only occurs in trace amounts below 18 mbsf. However, diagenetic silica phases in the form of "chert" beds and nodules make their first appearance at approximiately $120 \mathrm{mbsf}$ and occur in nearly all of the lower lying sediment cores. Figure 10 indicates that most of 
Table 6. Lithology summary for Site 738 from Barron, Larsen, et al. (1989).

\begin{tabular}{|c|c|c|c|}
\hline Epoch & Unit & $\begin{array}{l}\text { Depth } \\
\text { (mbsf) }\end{array}$ & Lithology \\
\hline Quaternary-upper Pliocene & IA & $0-10.2$ & Calcareous diatom ooze \\
\hline upper Pliocene-upper Miocene & IB & $10.2-16.8$ & Diatom ooze \\
\hline upper Miocene & II & $16.8-17.7$ & $\begin{array}{l}\text { Nannofossil ooze with minor } \\
\text { diatoms }\end{array}$ \\
\hline lower Oligocene-middle Eocene & III & $17.7-120.8$ & $\begin{array}{l}\text { Nannofossil ooze, homoge- } \\
\text { neous }\end{array}$ \\
\hline middle Eocene-lower Eocene & IV & $120.8-254.4$ & $\begin{array}{l}\text { Nannofossil ooze and chalk, } \\
\text { partially with chert }\end{array}$ \\
\hline $\begin{array}{l}\text { lower Eocene-lower Maestrichtian } \\
\text { to Campanian }\end{array}$ & V & $254.4-418.6$ & $\begin{array}{l}\text { Calcareous chalk, partially with } \\
\text { minor foraminifers, nanno- } \\
\text { fossils, and chert }\end{array}$ \\
\hline $\begin{array}{l}\text { lower Maestrichtian to Campanian- } \\
\text { lower Turonian }\end{array}$ & V1 & $418.6-479.7$ & $\begin{array}{l}\text { Limestone with minor clay and } \\
\text { chert }\end{array}$ \\
\hline lower Turonian or older & VIIA & $479.7-495.5$ & Calciclastic limestone \\
\hline lower Turonian or older & VIIB & $495.5-495.6$ & Basaltic breccia \\
\hline lower Turonian or older & VIII & $495.6-533.8$ & Basement \\
\hline
\end{tabular}
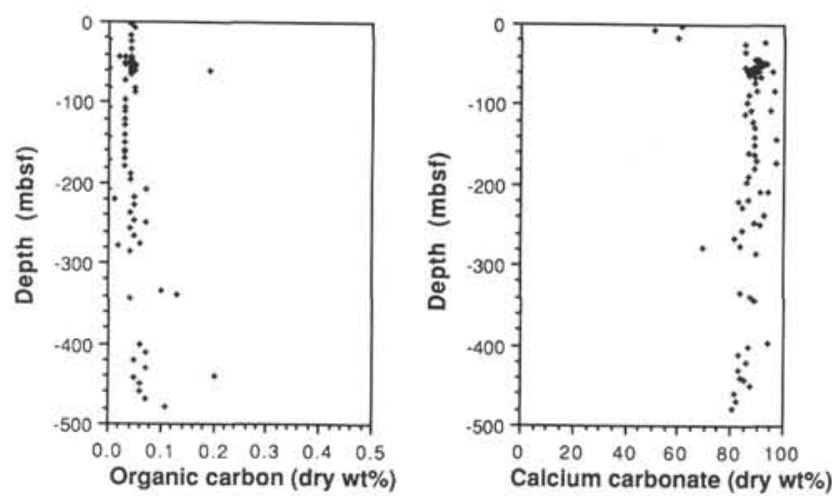

Figure 10. Organic carbon and calcium carbonate contents of Site 738 sediments. Plots incorporate data collected from ODP minicore samples (Table 3) and high-resolution samples (Cranston, this volume).

the sediments at Site 738 contain at least $80 \%$ calcium carbonate. These are undoubtedly maximum values, though, for most of the analyses were performed on the matrix material surrounding the chert beds and nodules.

Although the bulk of the sedimentary section consists of carbonate, diagenetic processes involving silicates have played an important role in defining the present physical properties of the sediment column. All of the lithologic units below $120 \mathrm{mbsf}$ contain diagenetic forms of silica. The chalks and limestones also exhibit a significant degree of silicification. Shipboard paleontologists noted that Campanian and older (approximately 409 mbsf and below) foraminifer tests are commonly filled with silica (Barron, Larsen, et al., 1989). X-ray-diffraction analyses of the chert beds and nodules produced opal-CT and quartz diffraction peaks (Barron, Larsen, et al., 1989). In addition, most of the smear slide descriptions of sediment samples from 120 mbsf and deeper levels reveal clay mineral contents of at least 5\% (Barron, Larsen, et al., 1989). The downward increase in silicification and carbonate recrystallization is accompanied by porosity and water content reductions from $75 \%$ to $20 \%$ and $55 \%$ to $10 \%$, respectively (Barron, Larsen, et al., 1989).

Volcaniclastic sediments and basalts recovered from 480 to $534 \mathrm{mbsf}$ contain numerous secondary phases. Vesicles in basalt clasts and basalts are commonly filled with clay minerals, silica phases, and carbonates (Barron, Larsen, et al., 1989). Plagioclase phenocrysts generally show signs of sericitization and carbonatization (Barron, Larsen, et al., 1989). Crystals of clinopyroxene and olivine are moderately to completely altered to clay minerals, and glassy matrix materials are usually recrystallized (Barron, Larsen, et al., 1989). All of these reactions affect porefluid chemistry to some degree.

Low sediment-accumulation rates on the SKP have resulted in low organic carbon contents and high oxidation-reduction potentials in Site 738 sediments. The average organic carbon content of Site 738 sediments is $0.04 \%$ (s.d. $=0.03 \%, \mathrm{n}=86$ ). This is a factor of 10 lower than the average organic matter contents calculated for Sites $736(0.4 \%)$ and $737(0.3 \%)$. Slow sedimentation permits organic matter to remain near the seafloor for long periods of time. This allows benthic organisms sufficient time to consume much of the organic matter before it can be buried by sediments. Cranston (this volume) has shown that sediment-accumulation rate and organic carbon content are linearly correlated in the pelagic sediments cored by DSDP and ODP. A small supply of reactable organic matter will limit the amount of microbial catabolism below the sediment/water interface and allow ample time for oxidants in ocean bottom waters to diffuse into the sediment column. The high oxidation-reduction potentials measured during high-resolution sampling (Cranston, this volume) at Site 738 suggest that a lack of reactable organic matter has, indeed, limited microbial activity within the sediment column.

\section{Interstitial-Water Chemistry}

A total of 89 samples was collected at Site 738 for interstitialwater chemical studies. Routine ODP sampling provided 13 minicores covering the depth range of 3-396 mbsf. Water contents at deeper levels fall below $20 \%$, precluding water extraction with the hydraulic press. The high-resolution program was able to continue sampling to a depth of $478 \mathrm{mbsf}$, allowing us to analyze pore fluids from sediments situated less than $10 \mathrm{~m}$ above basaltic basement rocks. Concentration-vs.-depth plots of the interstitial-water chemical data from the ODP minicore samples are displayed in Figure 11.

The near total absence of organic matter in Site 738 sediments places severe limitations on microbial activity below the seafloor. Dissolved sulfate concentrations decrease approximately $20 \%$ from typical seawater values in the first 50 mbsf. Below this depth, sulfate concentrations remain essentially constant (23.5 mM $\pm 0.5 \mathrm{mM}, \mathrm{n}=11$; Fig. 11). Most of the dissolved phosphate is also found in the uppermost 50 mbsf. Ammonium concentrations never exceed trace amounts. The sulfate data suggest that microbial sulfate reduction does occur in these sediments, and that it is only effective to a depth of about $50 \mathrm{mbsf}$. The other nutrient data indicate that very little organic matter is available for consumption. Pore-water alkalinities are slightly higher than seawater values near the sediment/water interface 

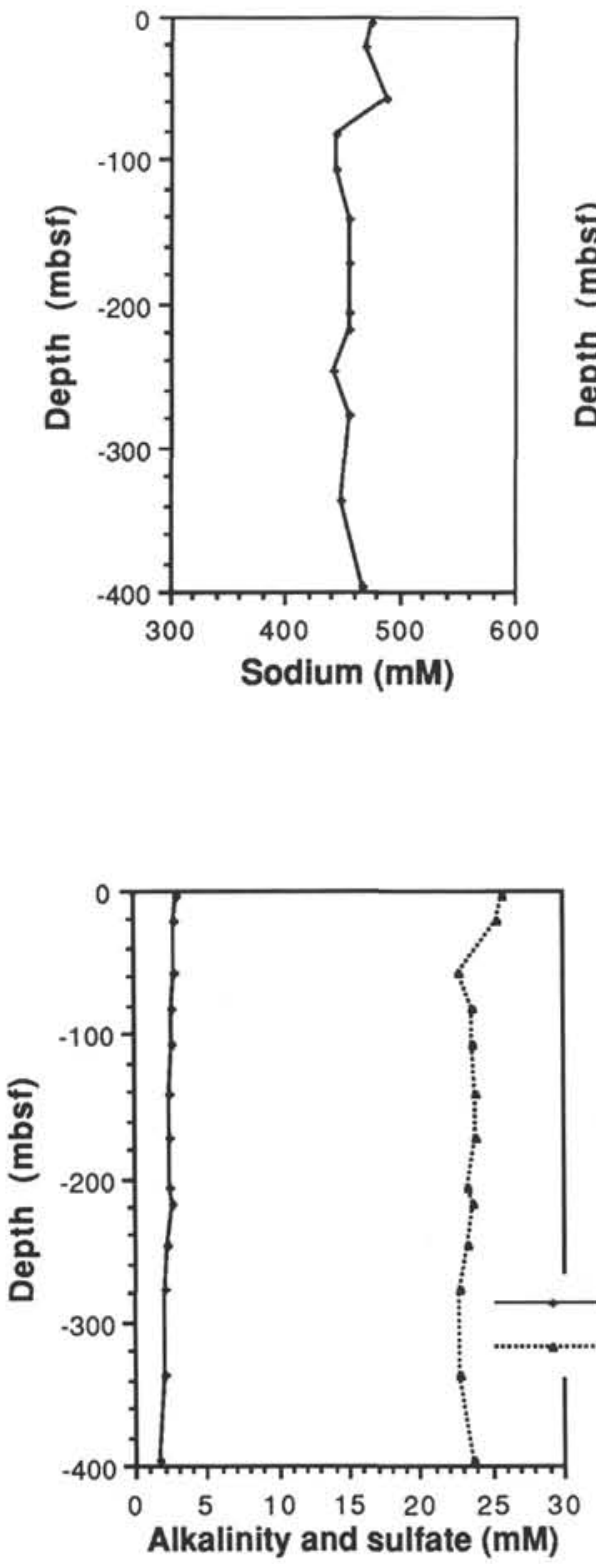

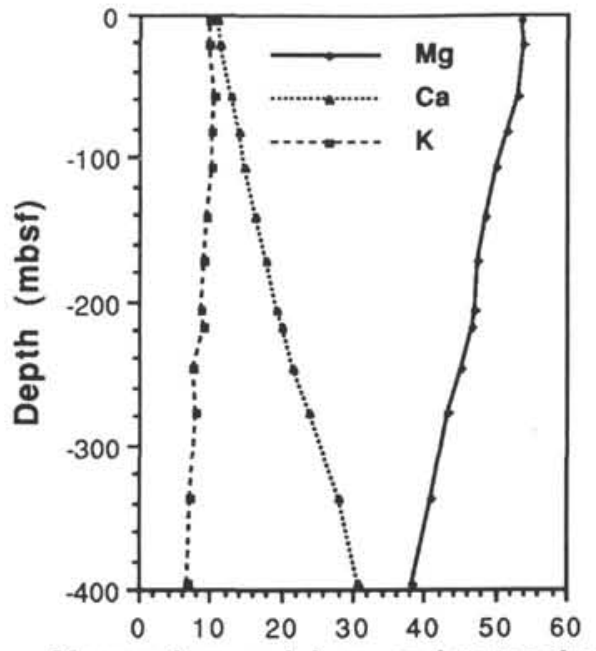

Magnesium, calcium, and potassium (mM)
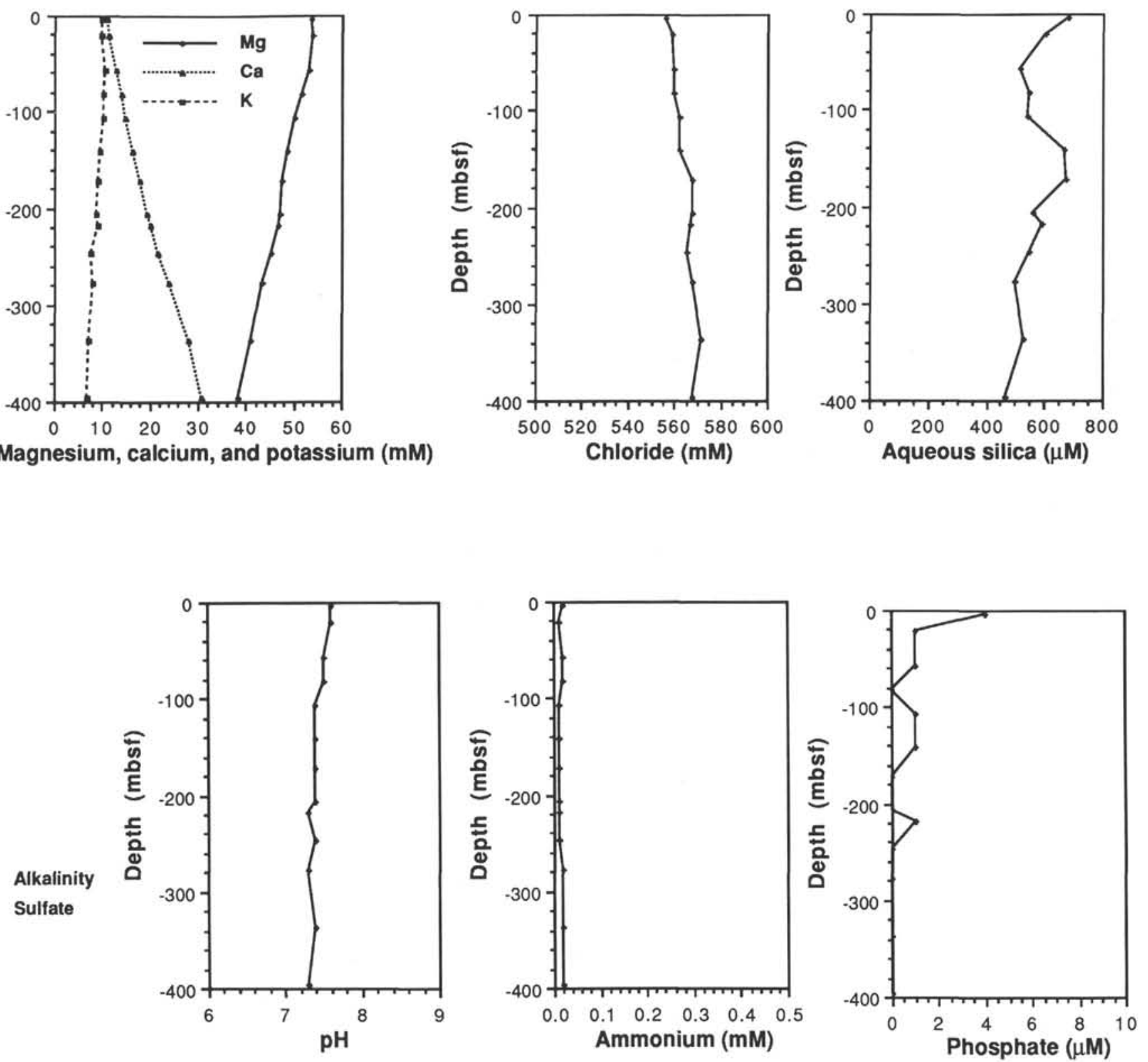

Figure 11. Interstitial water solute distributions at Site 738. 
but decrease $39 \%$ by 396 mbsf. Carbonate precipitation near the bottom of the sediment column and a slight decrease in $\mathrm{pH}$ with depth are the most probable causes of the decrease in alkalinity.

It is likely that the lack of sediment accumulation during the past $30 \mathrm{Ma}$ and generally low sedimentation rates have allowed sufficient time for most of the reactable organic matter trapped in the Site 738 sediments to be metabolized. All of the sediments below 20 mbsf at Site 738 are at least 30 m.y. old. The lack of a continuous supply of new organic matter to the seafloor limits the amount of microorganisms that the sediments can support and forces those that are present to metabolize less nutritious foodstuffs. This may explain the relatively high methane concentrations (1409 ppm at 2.94 mbsf; Barron, Larsen, et al., 1989) in the interstitial waters just below the sediment/water interface.

Most of the major pore-water cations at Site 738 have strong, linear concentration-vs.-depth correlations (Fig. 11). Dissolved magnesium $(r=-0.993, n=13)$ and potassium $(r=-0.936$, $\mathrm{n}=13$ ) concentrations decrease $28 \%$ and $36 \%$, respectively, between 3 and 396 mbsf. Interstitial-water calcium concentrations $(r=0.994, n=13)$ increase $177 \%$ within the same depth range. Figure 12 illustrates the good correlations between these chemical species. Dissolved sodium concentrations do not display a depth gradient at Site 738 (mean $=490 \mathrm{mM} \pm 3 \%, \mathrm{n}=$ 13; standard deviation is equal to analytical precision).

Major cation fluxes are much more subdued at Site 738 than, those observed on the NKP at Site 737. As Table 5 shows, we have estimated that the cation diffusion coefficients at Site 738 are approximately half as large as those used for Site 737 . Resistivity measurements made during downhole logging operations at these sites support this assumption. Ions do not diffuse through different types of sediments at the same rate. The more permeable a sediment is to fluid flow, the less resistive it will be to the diffusion of dissolved ions and molecules. The magnitude of ion diffusion coefficients reflects the ease with which they can move through sediments. Electrical resistivity measurements of wet sediments provide a means of relating the ease with which ions can travel through different sediment pore-water systems.

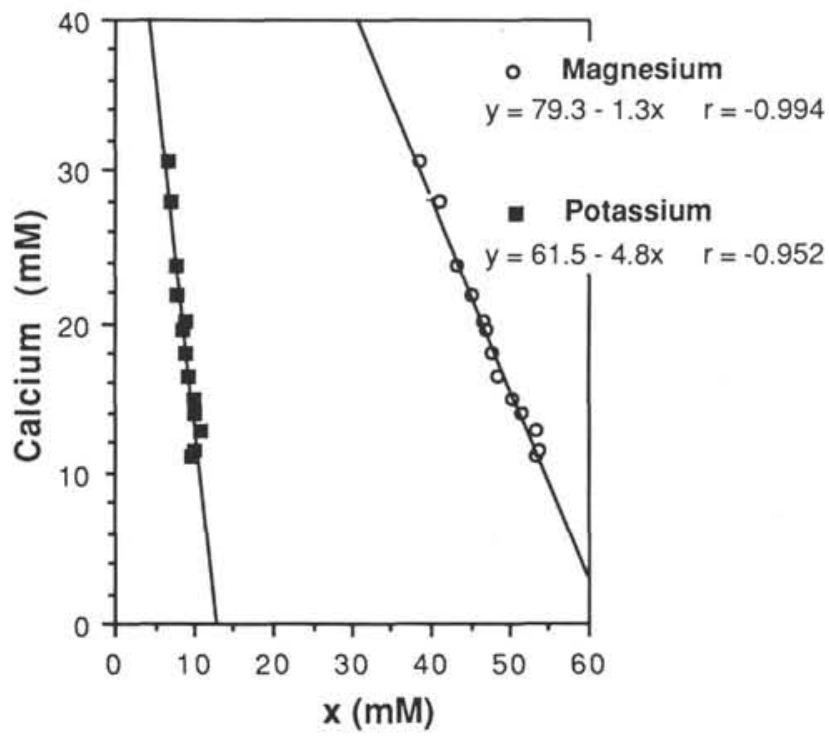

Figure 12. Major cation correlations for Site 738 interstitial waters. Solid lines represent linear least-square regressions through the chemical data. Equations and correlation coefficients for each line are also shown.
An empirical relationship can be used to relate bulk sediment resistivities to diffusion coefficients:

$$
\begin{aligned}
\mathrm{D}_{\mathrm{b}} & =\mathrm{D}_{\mathrm{w}} /(\phi \mathrm{F}) \\
\mathrm{F} & =\mathrm{R}_{\mathrm{b}} / \mathrm{R}_{\mathrm{w}}
\end{aligned}
$$

where $D_{b}$ is the bulk-sediment diffusion coefficient, $D_{w}$ is the diffusion coefficient in pore water, $\phi$ is porosity, $\mathrm{F}$ is a number known as the formation factor, $\mathrm{R}_{\mathrm{b}}$ is the resistivity of the sediment-porewater system, and $R_{w}$ is the electrical resistivity of the pore water (Berner, 1980). Resistivity logging at Sites 737 and 738 indicates that bulk-sediment resistivities are about twice as large at Site 738 (Barron, Larsen, et al., 1989). This difference is in good agreement with the formation factors for clayey diatom ooze $(F=1.6-1.9)$ and clayey nannoplankton ooze $(F=2.0$ 4.1) listed by Berner (1980) from the data of Manheim and Waterman (1974). As equation 7 shows, doubling the formation factor reduces the bulk-diffusion coefficient by one-half. The equation also shows that the assumption of constant diffusion coefficients with increasing depth is a poor one for these sites due to their sharp decreases in porosity. Nevertheless, the fluxes shown in Table 5 provide a good relative measure of the chemical stability of the sediment-interstitial-water systems at these sites.

While the interstitial-water chemical gradients are substantial at Site 738 , the dissolved major cation fluxes indicate that the sediment system is slowly equilibrating with the overlying water column. The concentrations of calcium, magnesium, and potassium in the interstitial waters at this site are primarily controlled by diffusion between the seafloor and $400 \mathrm{mbsf}$. The fluxes of calcium, magnesium, and potassium are factors of 10, 6, and 4, respectively, smaller at Site 738 than at Site 737 (Table 5). In addition, a strong sodium flux occurs at Site 737 but is absent at Site 738 . The concentration gradients present at Site 738 are largely the result of slow diffusion between the basement rocks and the seafloor. The lack of a sodium gradient at Site 738 suggests that the reactivity of sodium at Site 737 is tied to the alteration of volcanic debris, which is not present in abundance at Site 738. Thus, the large quantities of clay minerals in the deeper sediments at Site 738 may represent the alteration of volcanic debris millions of years ago. The abundance of alteration features in the sediments and basement rocks recovered on the SKP and the low major cation fluxes indicate that water-rock interactions are on the wane.

Aqueous silica concentrations at Site 738 are partially controlled by shifts in sediment composition. The diatom oozes that cap the sedimentary sequence are associated with relatively high interstitial-water silica concentrations (Fig. 11). Dissolved silica concentrations decrease with depth in the uppermost 40 mbsf as biogenic silica disappears from the sediments. Data from both interstitial-water programs (Fig. 13) indicate that there is no discernible aqueous silica gradient from 40 to 400 mbsf.

The ODP sampling program missed a significant pore-water chemistry anomaly due to its inability to obtain water samples below 400 mbsf. As Figure 13 illustrates, there is a sharp increase in dissolved silica below $400 \mathrm{mbsf}$. Silica is being supplied to the interstitial waters from sources at the top and at the bottom of the sediment column. Weathering reactions involving the basement basalts are the most likely deep silica source. The thermal gradient measured on the SKP indicates that the temperature near the bottom of Hole $738 \mathrm{C}$ was approximately $22^{\circ} \mathrm{C}$; the present thermal regime does not appear to be conducive to advanced silica diagenesis. Thus, most of the abundant chert layers and nodules found in Eocene and older sediments at Site 


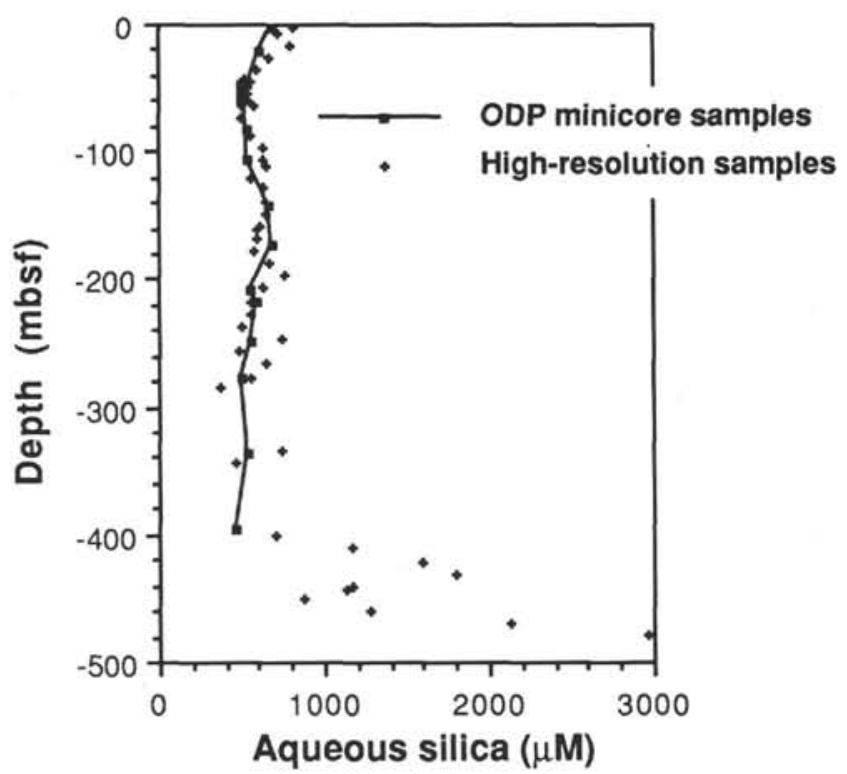

Figure 13. Concentration-vs.-depth plot of aqueous silica at Site 738 incorporating data from standard ODP minicore samples (solid line) and high resolution samples (Cranston, this volume). Note the good agreement between data from both sampling programs and the sharp increase in aqueous silica below $400 \mathrm{mbsf}$ that was missed by routine ODP sampling.

738 were probably formed millions of years ago. It is likely that the excess supply of aqueous silica in the deeper sediments is responsible for the consumption of dissolved potassium and magnesium through the precipitation of authigenic silicates.

\section{Site 744}

\section{Sediment Characteristics}

Site 744 was established $170 \mathrm{~km}$ to the northwest of Site 738 in an attempt to recover a relatively complete Neogene sedimentary record. To this end, coring in three holes retrieved $176.1 \mathrm{~m}$ of uppermost Eocene to Quaternary sediments from the seafloor. Although paleontologists have identified four hiatuses, or compressed intervals, approximately $100 \mathrm{~m}$ of the section represents Neogene sedimentation (Barron, Larsen, et al., 1989).

The sediments cored at Site 744 can be logically separated into two lithologic units. Unit I extends from the seafloor to 23 mbsf. This uppermost unit consists of diatom ooze with a variable carbonate component (Fig. 14). On average, Unit I contains $25 \%$ calcium carbonate (s.d. $=21 \%, \mathrm{n}=12$ ) and $0.09 \%$ organic carbon (s.d. $=0.02 \%, \mathrm{n}=9$ ). With increasing depth, Unit I grades into the calcareous nannofossil oozes of Unit II. The latter unit is comprised of approximately $71 \%$ calcium carbonate (s.d. $=10 \%, \mathrm{n}=30$ ) and $0.03 \%$ organic carbon (s.d. $=$ $0.006 \%, \mathrm{n}=24$; Fig. 14). Terrigenous detritus is a minor component in both units.

Site 744 is similar to Site 738 in that persistently low sediment-accumulation rates have resulted a lack of significant organic carbon burial and relatively high oxidation-reduction potentials below the sediment/water interface. Sediment-accumulation rates average $4.6 \mathrm{~m} / \mathrm{m}$.y. and never exceed $10 \mathrm{~m} / \mathrm{m}$.y. over the cored interval at Site 744 (Barron, Larsen, et al., 1989). The bioturbation noted at this site attests to the fully aerobic depositional environments that have existed there since the latest Eocene (Barron, Larsen, et al., 1989). Quantitative evidence for oxidizing conditions in the modern sedimentary system comes
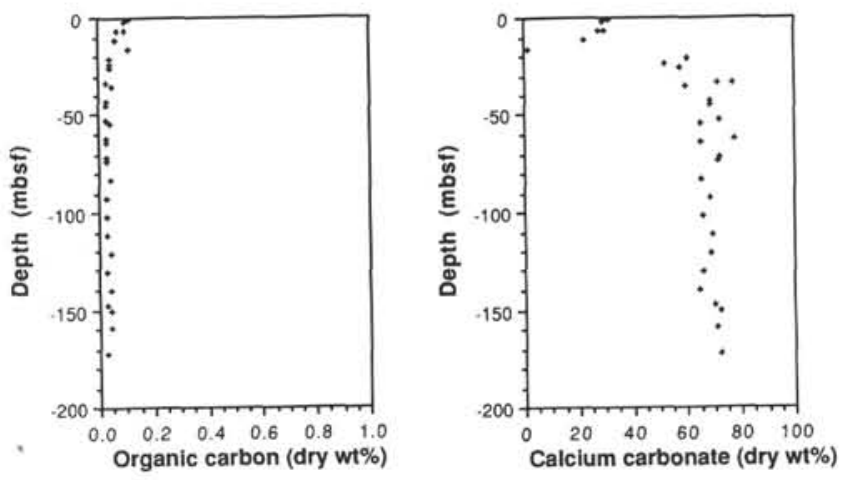

Figure 14. Organic carbon and calcium carbonate contents of Site 744 sediments. Plots incorporate data collected from ODP minicore samples (Table 3) and high-resolution samples (Cranston, this volume).

from the high oxidation-reduction potentials measured in conjunction with the high-resolution program (see Cranston, this volume). These conditions suggest that most of the organic matter that reaches the seafloor at Site 744 is oxidized before it can be incorporated into the sediments.

\section{Interstitial-Water Chemistry}

Despite the presence of a much more extensive Neogene sediment section, the interstitial-water chemistry of Site 744 is remarkably similar to that of Site 738. A total of 48 samples was collected from Site 744 cores for this study. Concentration-vs.depth plots of the 16 ODP water samples portray a relatively unreactive sediment column that supports little microbial activity (Fig. 15).

Alkalinity and nutrient concentrations in Site 744 interstitial waters confirm that microbial activity is severely limited by the absence of reactive organic matter. Pore-water alkalinities are only slightly higher than typical seawater values and remain nearly constant to at least 163 mbsf $($ mean $=2.86 \mathrm{mM}$, s.d. $=$ $0.14, \mathrm{n}=16$ ). The average dissolved sulfate concentration for this data set $($ mean $=28.2 \mathrm{mM}$, s.d. $=1.3, \mathrm{n}=16)$ is very close to that of local seawater. Samples extracted from lithologic Unit I are the only ones that contain measurable phosphate concentrations. In addition, ammonium is essentially absent from all of the samples. All of these data taken together indicate that the sediments remain oxic to a depth of at least $163 \mathrm{mbsf}$. The small amount of organic matter that is being buried at Site 744 is insufficient for the maintenance of a significant population of microorganisms below the sediment-water interface.

The vertical fluxes of major dissolved cations at Site 744 are small. As Table 5 indicates, the concentration-vs.-depth gradients and fluxes of magnesium, calcium, and potassium are $22 \%$, $20 \%$, and $50 \%$ smaller the values calculated for Site 738 . In addition, there is no measurable dissolved sodium gradient at Site 744 (mean $=478 \mathrm{mM}$, s.d. $=7 \mathrm{mM}, \mathrm{n}=16$ ). The strong correlations between pore-water magnesium, calcium, and potassium illustrated in Figure 16 imply that these species behave conservatively in the sediments cored at Site 744 . While it is impossible to say with certainty what processes are responsible for the observed cation gradients, it is likely that weathering reactions involving basaltic basement rocks at greater depths are driving the diffusion of these elements.

Aqueous silica concentrations do not exhibit significant variations in the depth interval sampled at Site 744. Dissolution of the abundant biogenic silica contained in lithologic Unit $I$ is the main source of pore-water silica in the these samples. The fact that aqueous silica concentrations remain high (mean $=658$ 

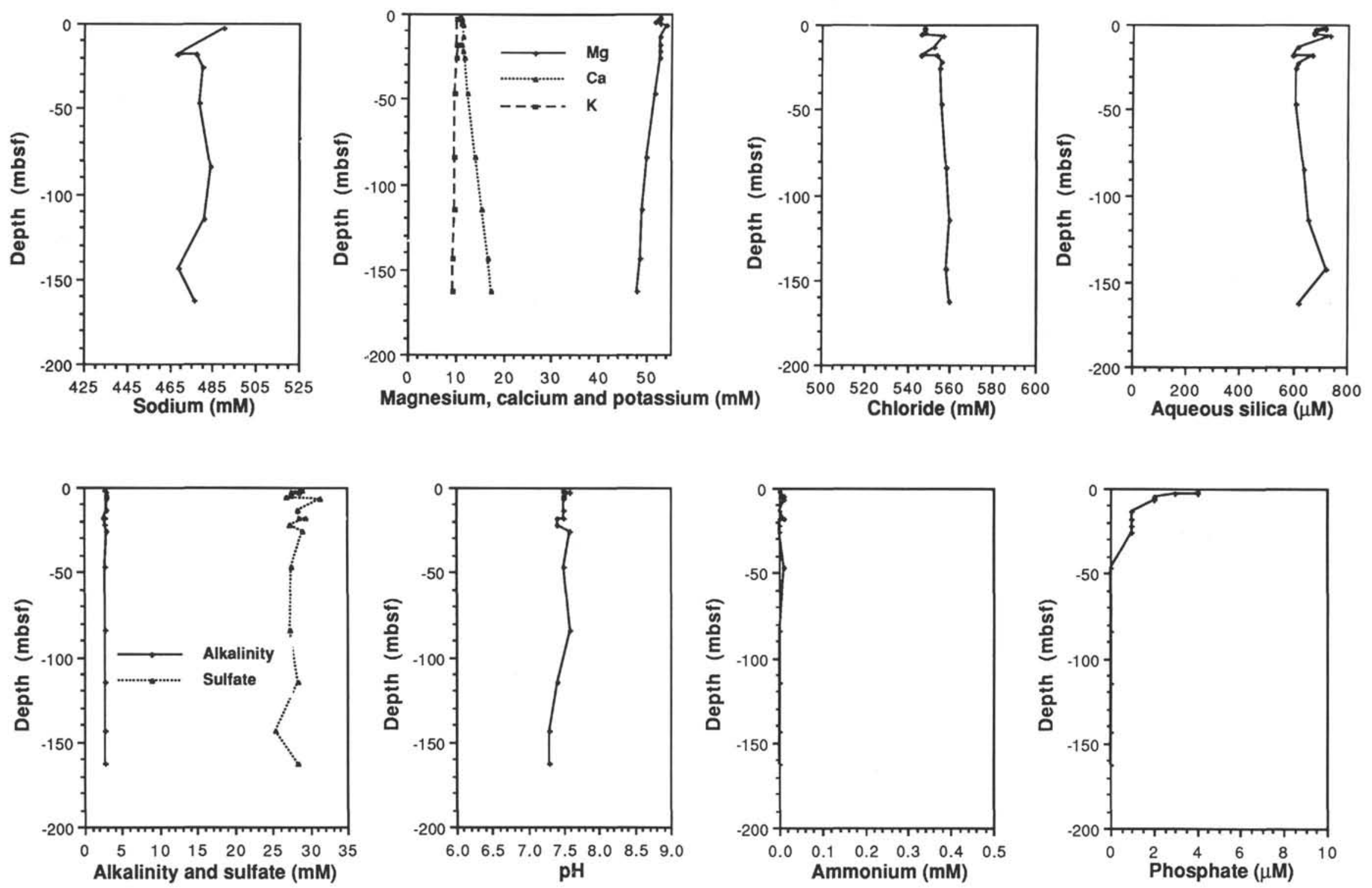

Figure 15. Interstitial water solute distributions at Site $\mathbf{7 4 4 .}$ 


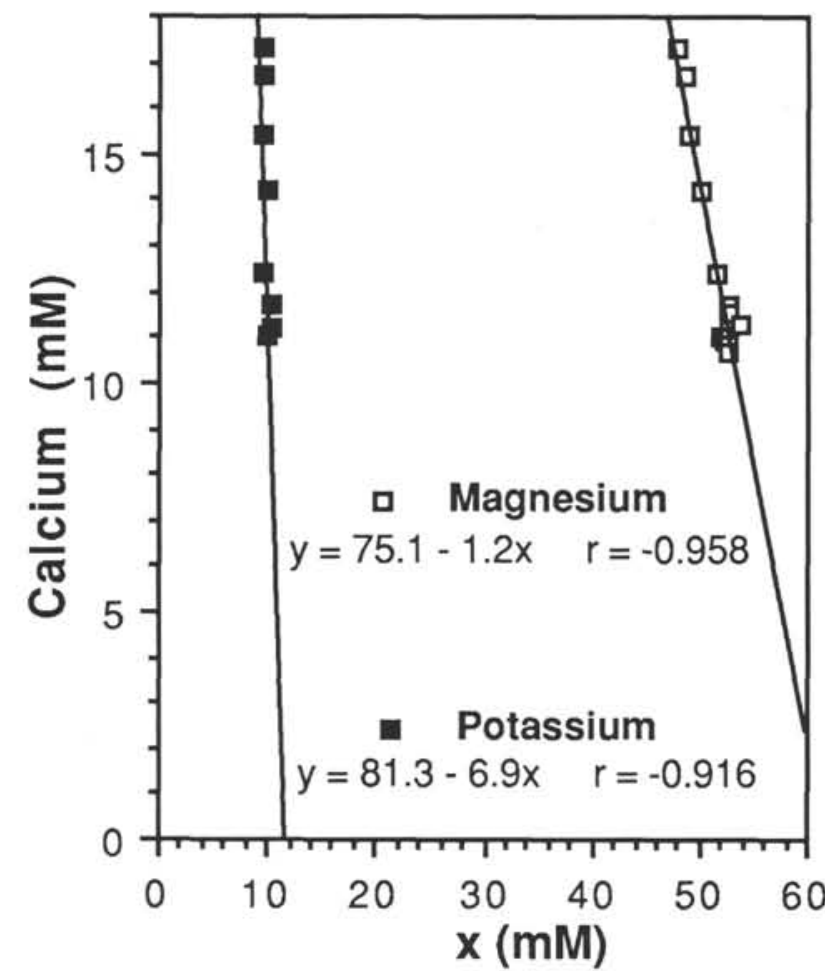

Figure 16. Major cation correlations for Site 744 interstitial waters. Solid lines represent linear least-square regressions through the chemical data. Equations and correlation coefficients for each line are also shown.

$\mu \mathrm{M}$, s.d. $=47 \mu \mathrm{M}, \mathrm{n}=16)$ with increasing depth requires either a strong downward flux of silica from Unit I or the existence of another silica source at deeper levels.

\section{Eastern Kerguelen Sediment Ridge (Sites 745 and 746)}

The Eastern Kerguelen Sediment Ridge is a large, elongate sediment drift that parallels the southeastern slope of the Kerguelen Plateau (Fig. 1). Sites $745\left(59^{\circ} 35.71^{\prime} \mathrm{S}, 85^{\circ} 51.60^{\prime} \mathrm{E}\right.$, water depth $=4082.5 \mathrm{~m})$ and $746\left(59^{\circ} 32.82^{\prime} \mathrm{S}, 85^{\circ} 51.78^{\prime} \mathrm{E}\right.$, water depth $=4059.5 \mathrm{~m}$ ) were established to obtain a deep-water paleoceanographic record for the southern Indian Ocean. The move $5 \mathrm{~km}$ north to Site 746 was mandated by marauding icebergs in the vicinity of Site 745 . Water depths in excess of $4 \mathrm{~km}$ place the sediment ridge within Antarctic Bottom Water and near the level of the regional CCD. Three holes were cored to a total depth of $280.8 \mathrm{mbsf}$, and $325.65 \mathrm{~m}$ of upper Miocene to Quaternary sediments was recovered. Seismic-reflection studies suggest that the thickness of the entire sedimentary section at Site 745 is 1359 m (Barron, Larsen, et al., 1989). Temperature measurements at Site 745 revealed a seafloor temperature of $0^{\circ} \mathrm{C}$ and a thermal gradient of $83^{\circ} \mathrm{C} / \mathrm{km}$ (Barron, Larsen, et al., 1989). As stratigraphic datums appear to lie at similar depths at Sites 475 and 746, they will be treated as a single site in the following discussion.

\section{Sites 745 and 746}

\section{Sediment Characteristics}

The sediments recovered at Sites 745 and 746 range in composition from diatom ooze to diatomaceous clay. They have both pelagic and terrigenous sources and accumulated at a rate of $30 \mathrm{~m} / \mathrm{m}$.y. (Barron, Larsen, et al., 1989). Shipboard smear slide descriptions indicated a downward increase in clay mineral contents (Barron, Larsen, et al., 1989). Minor volcanic ash lay- ers were noted at Site 745 (Barron, Larsen, et al., 1989). As Figure 17 illustrates, moderate sedimentation rates have resulted in an average organic carbon content (mean $=0.15 \%$, s.d. $=$ $0.07 \%, \mathrm{n}=49$ ) that is intermediate to values measured on the NKP and SKP. With the exception of a 58-cm bed of nannofossil ooze at $246.7 \mathrm{mbsf}$ of Site 746 , deposition below the regional $\mathrm{CCD}$ has produced carbonate-free sediments at these sites (Fig. 17).

Visual evidence for diagenetic processes operating at Sites 745 and 746 is limited to ichnofabric and color banding. The presence of both bioturbated and laminated intervals implies that dissolved oxygen concentrations near the sediment/water interface have fluctuated through time. The presence of a pyrite-filled burrow at $67.3 \mathrm{mbsf}$ in Hole 745B (Barron, Larsen, et al., 1989) attests to the presence of at least temporary and/or local anaerobic conditions. Color banding that overprints sedimentary structures is a common feature in these sediments and its presence appears to be correlated with clay-rich sediment layers (Barron, Larsen, et al., 1989). It is likely that this banding is an early diagenetic feature.

\section{Interstitial-Water Chemistry}

Interstitial-water sampling at Sites $\mathbf{7 4 5}$ and $\mathbf{7 4 6}$ covered strata from 2.2 to $252.4 \mathrm{mbsf}$ and provided a total of 49 samples for analysis. Concentration-vs.-depth plots of the dissolved constituents in pore waters extracted from 14 ODP minicores are shown in Figure 18. Temperature measurements at Site 745 indicate that the in-situ temperature of the deepest sample retrieved at Site 746 was approximately $21^{\circ} \mathrm{C}$. Thus, as is true of all ODP interstitial-water studies, some of the shallower samples may have been enriched in monovalent cations and silica and depleted in divalent cations as a result of warming prior to fluid extraction.

Although they contain less organic matter and accumulated at slower rates than the NKP sites, sediments on the Eastern Kerguelen Sediment Ridge exhibit the most robust microbial activity of all the Kerguelen Plateau regions that we have studied. Dissolved sulfate concentrations decrease $41 \%$ within the sampling interval of Sites 745 and 746 (Fig. 18). Pore water alkalinity increases to the highest values measured on the Kerguelen Plateau $(6.77 \mathrm{mM})$ within the first $100 \mathrm{mbsf}$ and remains at this elevated level to the bottom of Hole 745B (Table 2). Samples from similar depths have lower alkalinities at Site 746 than at Site 745 , indicating that microbial activity may be slightly weaker at the former site. The highest ammonium $(0.50 \mathrm{mM})$ and phosphate $(23 \mu \mathrm{M})$ concentrations in Kerguelen Plateau pore waters were measured at Sites 745 and 746 (Table 2). Ammonium con-
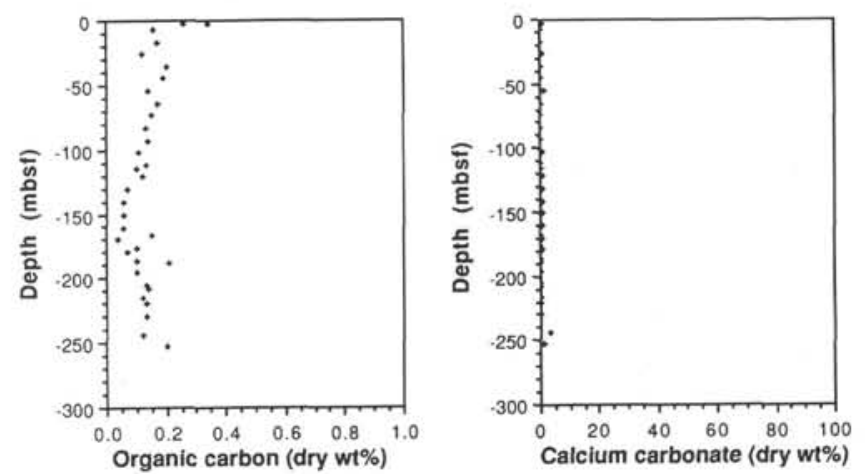

Figure 17. Organic carbon and calcium carbonate contents of sediments from Sites 745 and 746. Plots incorporate data collected from ODP minicore samples (Table 3) and high-resolution samples (Cranston, this volume). 

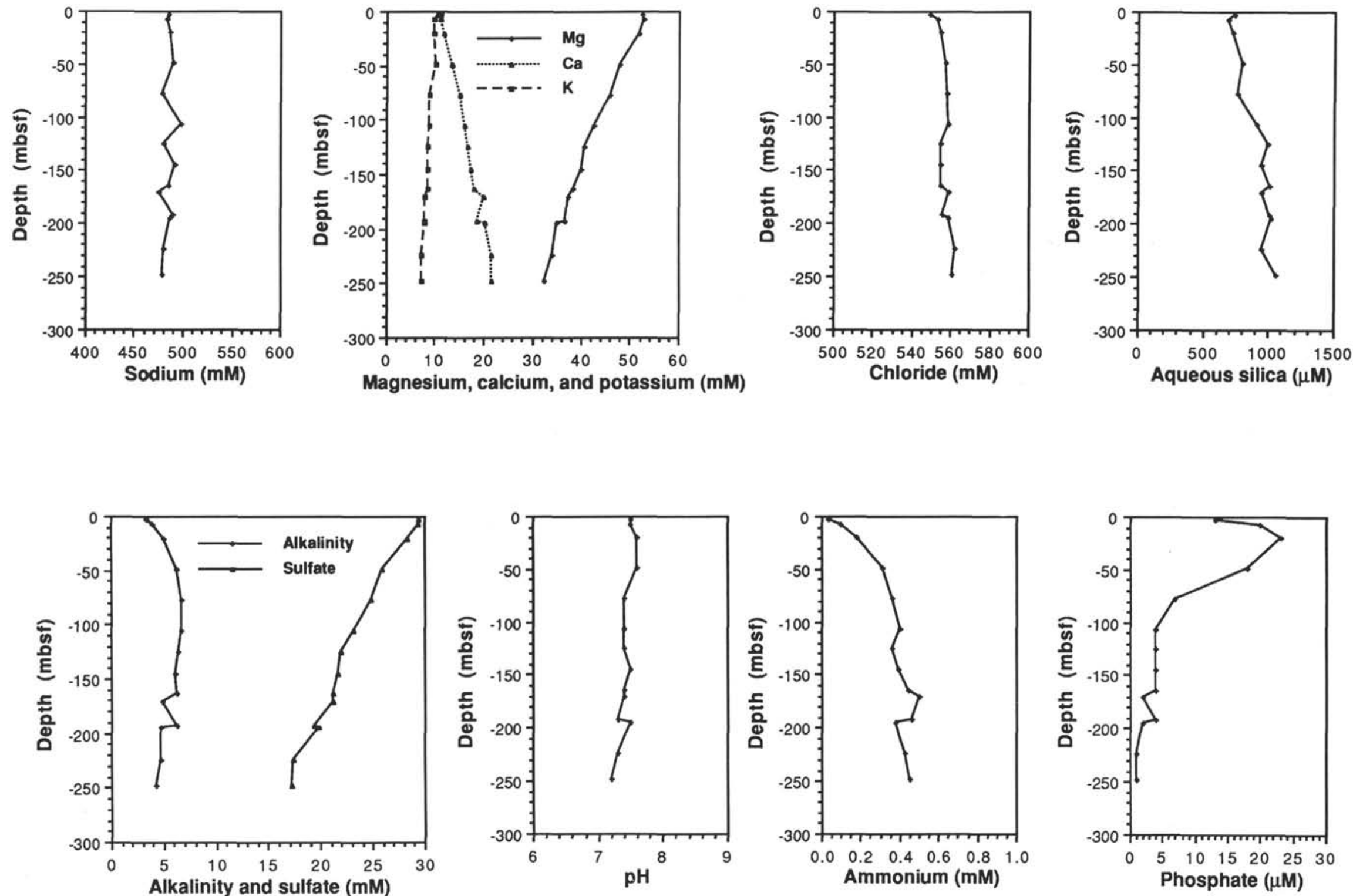

Figure 18. Interstitial water solute distributions at Sites 745 and 746. 
centrations increase most rapidly in the uppermost $50 \mathrm{mbsf}$, but continue to increase with depth (Fig. 18). A sharp maximum exists near 20 mbsf in the concentration-vs.-depth plot of dissolved phosphate (Fig. 18). Electrode potential (pe) measurements of the high-resolution sediment samples (Fig. 19) reveal a very sharp drop in the oxidation-reduction potential near 150 mbsf.

The sulfate, ammonium, phosphate, and pe data indicate that bacterial catabolism is affecting interstitial-water chemistry over the entire depth range sampled at Sites 745 and 746. Clearly, the zone of maximum phosphate release to the pore waters occurs near 20 mbsf (Fig. 18). The oxidation-reduction potentials begin to decrease near $70 \mathrm{mbsf}$ and indicate that strongly reducing conditions exist below 150 mbsf (Fig. 19). The continued decrease of dissolved sulfate and increase of dissolved ammonium at $250 \mathrm{mbsf}$ requires that microbial activity exists at even deeper levels (Fig. 18). High pe values (approximately 5) at $20 \mathrm{mbsf}$ imply that aerobic processes may be responsible for most of the phosphate production at that depth. Sediments below $70 \mathrm{mbsf}$ must be anoxic. Bacterial sulfate reduction occurs to at least a depth of $250 \mathrm{mbsf}$ and appears to have generated much of the ammonium measured in the deepest samples (Fig. 18).

Major cation concentrations are diffusion controlled in the sediment-pore water system sampled at Sites 745 and 746. Dissolved sodium concentrations do not change significantly between the seafloor and 250 mbsf (mean $=485 \mathrm{mM}$, s.d. $=$ $6 \mathrm{mM}, \mathrm{n}=14)$. Magnesium, calcium, and potassium concentrations are strongly correlated in the samples that we have analyzed (Fig. 20). The data indicate that none of the major dissolved cations are involved in reactions within the sediment column at these sites.

Sites 745 and 746 are the only Kerguelen Plateau sites studied during Leg 119 that are characterized by dissolved magnesium

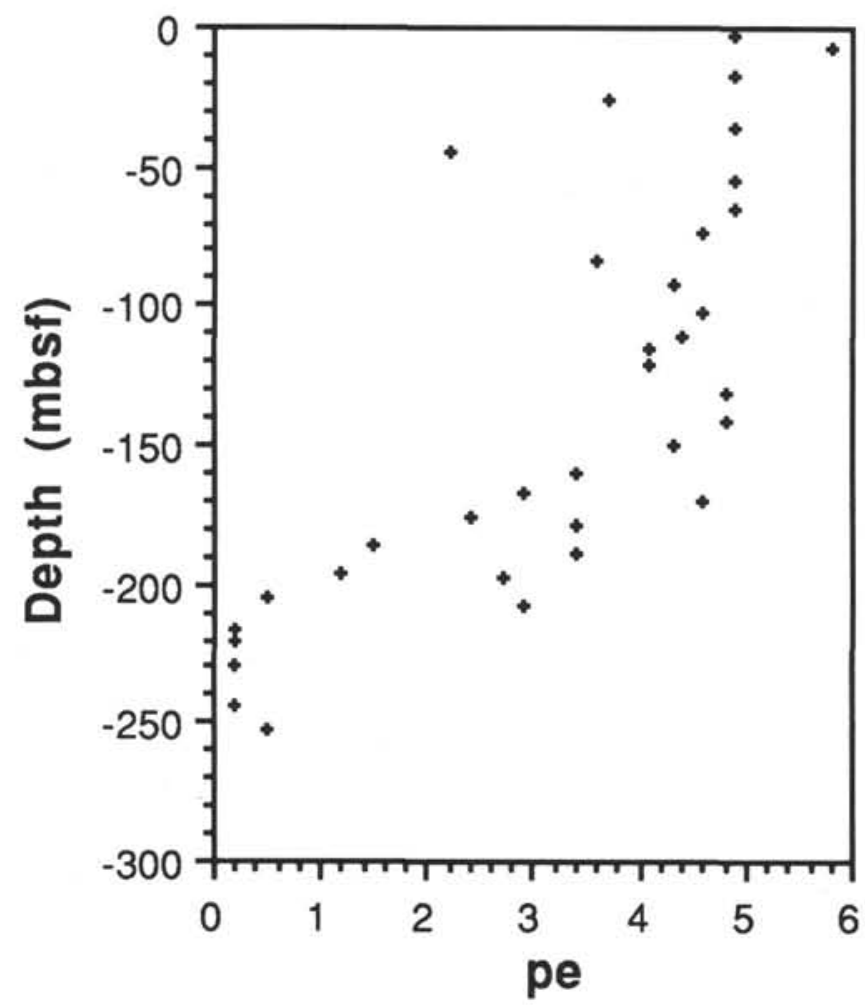

Figure 19. Oxidation-reduction potential measurements at Sites 745 and 746 using data from Cranston (this volume). Note the sharp decrease in pe below $150 \mathrm{mbsf}$.

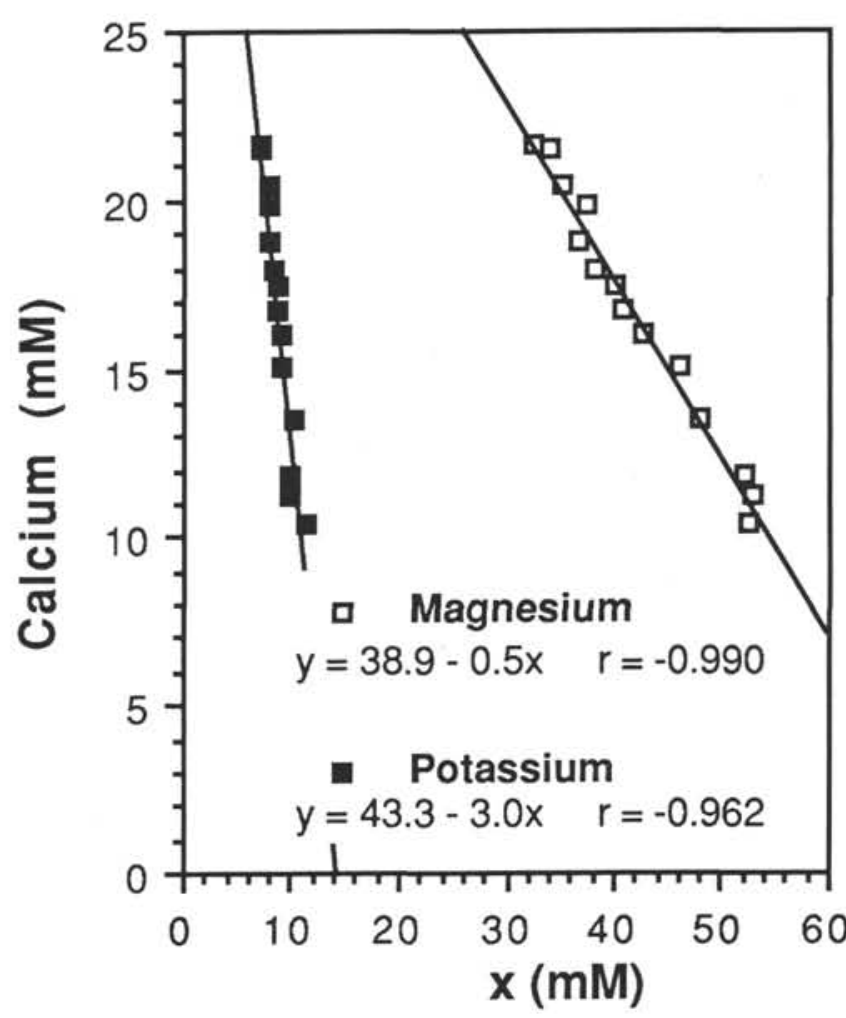

Figure 20. Major cation correlations for interstitial waters from Sites 745 and 746 . Solid lines represent linear least-square regressions through the chemical data. Equations and correlation coefficients for each line are also shown.

fluxes that are in excess of their dissolved calcium fluxes (Table 5 ). The diffusive fluxes of magnesium, potassium, and calcium at Sites 745 and 746 are intermediate to the fluxes calculated for the NKP and SKP sites. At all of the Kerguelen Plateau sites magnesium and potassium are diffusing into the sediments from the seafloor, while calcium is produced at depth and diffuses upward, toward the seafloor. Sites 745 and 746 are unusual, however, in that the downward flux of magnesium is $86 \%$ greater than the upward flux of calcium. In addition, the magnitude of the potassium flux is nearly as large as the calcium flux. Charge balance in the interstitial waters is maintained by the strong downward flux of sulfate from the seafloor. The good correlations between dissolved sulfate concentrations and magnesium $(\mathrm{r}=0.991, \mathrm{n}=14)$ and potassium $(\mathrm{r}=0.946, \mathrm{n}=14)$ concentrations suggest the interesting possibility that the uptake of the latter two species may be partially tied to microbial sulfate reduction and the associated redox changes.

Aqueous silica concentrations steadily increase with increasing depth at Sites 745 and 746, attesting to the continual dissolution of diatom tests within the sediment column. In contrast to the NKP and SKP sites, no other indications of silica diagenesis are apparent on the Eastern Kerguelen Sediment Ridge.

\section{SUMMARY AND CONCLUSIONS}

With the unique advantage of two sampling programs, we have provided the first glimpse at the sediment-pore water system operating on the Kerguelen Plateau. The standard ODP interstitial-water sampling program suffers from low sample density and inadequate handling of sediments with low in-situ temperatures. In the interest of obtaining the best samples possible, we recommend a return to the use of glove boxes and cooling jackets when liberating pore fluids from shallow sediment sam- 
ples by means of the hydraulic press. The high-resolution sampling program instituted during Leg 119 by Cranston (this volume) readily employed similar equipment. While the standard ODP sampling program reveals the general features of interstitial-water solute distributions, the high-resolution technique enabled us to pinpoint reaction zones and extend our data base to deeper, dryer levels that were heretofore inaccessible. We feel that this technique should merit serious consideration on future ODP voyages that require detailed interstitial-water chemical studies.

Leg 119 cored sediments at three widely separated Kerguelen Plateau localities. The six sites that we have studied permit a regional perspective of the interstitial-water solute distributions of the plateau. Northern Kerguelen Plateau Site 736 and 737 lie in shallow water (less than $700 \mathrm{~m}$ ) near Kerguelen Island. Approximately $1600 \mathrm{~km}$ to the southeast, Southern Kerguelen Plateau Sites 738 and 744 lie at intermediate depths (approximately $2,300 \mathrm{~m}$ ) in an area protected from terrigenous input. Deep-water Sites 745 and 746 were cored on the Eastern Kerguelen Sediment Ridge.

Analyses of sedimentary pore fluids provide a powerful context to establish the chemical stability of the ocean-upper crust couple. The following outline summarizes the principal findings of the Kerguelen Plateau portion of the Leg 119 interstitial-water chemistry program:

1. Northern Kerguelen Plateau. The northern sector is characterized by the highest sedimentation rates and thermal gradients that were encountered on the Kerguelen Plateau during Leg 119. The dual contribution of siliceous phytoplankton tests and volcanic debris from Kerguelen and Heard islands has resulted in thick accumulations of siliceous Neogene sediments on the NKP. Lower Neogene and older sediments grade into more carbonate-rich oozes, chalks, and limestones. High sedimentation rates have resulted in greater organic matter burial and thicker sedimentary sequences (up to $3 \mathrm{~km}$ ) than on other regions of the Kerguelen Plateau. Thick, insulating sequences of sediments are partially responsible for thermal gradients approaching $100^{\circ} \mathrm{C} /$ $\mathrm{km}$. Elevated temperatures have promoted silica diagenesis and the alteration of volcanic material below $300 \mathrm{mbsf}$.

Site 737 represents the most reactive sediment column cored thus far on the Kerguelen Plateau. Despite the relatively small supply of organic matter (mean $=0.3 \%$ ), bacterial sulfate reduction occurs over an extended depth interval. The coincidence of a dissolved sulfate minimum and an abrupt drop in oxidation-reduction potential indicates that the most intense zone of microbial activity occurs near 380 mbsf. Major cation fluxes at Site 737 are the strongest measured during Leg 119. Some of the highest dissolved calcium concentrations ever recorded in pelagic marine sediments were encountered near the bottom of Hole 737B. The resulting chemical potential gradient drives a strong flux of calcium toward the seafloor. The high calcium concentrations precipitate pore-fluid alkalinity. Sodium, magnesium, and potassium are also precipitated from interstitial waters below 370 mbsf. The near absence of dissolved magnesium and potassium below this level verifies that their sinks reside in the sediment column. That the only observed dissolved sodium concentration-vs.-depth gradient occurs in sediments with abundant volcanic debris suggests that sodium is consumed during the alteration of this unstable material.

One of the most significant results of the NKP interstitialwater studies is the identification of a diagenetic front operating near 370 mbsf at Site 737. The deflection of major cation concentration-vs.-depth gradients and a sharp drop in aqueous silica concentrations signal the precipitation of authigenic silicates at this depth. Calcium is released, and sodium, magnesium, and potassium are withdrawn from pore waters during the alteration of the abundant volcanic debris observed in this portion of the sediment column. The occurrence of chert layers below $300 \mathrm{mbsf}$ suggests that this is also a zone of active silica diagenesis. This silicification front coincides with a sharp drop in oxidation-reduction potential, a dissolved sulfate minimum, and a $\mathrm{pH}$ increase. Abrupt increases in electrical resistivity and sonic velocity imply that these diagenetic processes are accompanied by a porosity loss and an increase in sediment lithification. The observed chemical and physical anomalies can be explained by the upward movement of a diagenetic front depositing authigenic silicates, diagenetic silica, and calcium carbonate. These reactions would result in porosity and permeability reductions that would cut off diffusive transport through deeper sediment layers and move the focus of microbial activity upward.

2. Southern Kerguelen Plateau. In contrast to the northern region, the southern portion of the Kerguelen Plateau experiences the lowest sedimentation rates and thermal gradients of the three study areas. Extremely low average sediment-accumulation rates (less than $5 \mathrm{~m} / \mathrm{m}$.y.) have produced relatively thin sedimentary sequences that are nearly barren of organic matter. Terrigenous input to these sediments has been minimal. Thin layers (approximately $20 \mathrm{~m}$ ) of Neogene diatom oozes cover carbonate sediments in various stages of diagenetic transformation. Chert beds and nodules are abundant below $120 \mathrm{mbsf}$ at Site 738. Complete penetration of the sedimentary sequence at Site 738 allowed us to trace interstitial-water solute distributions down to the underlying basalt.

The absence of reactable organic matter in SKP sediments severely limits the intensity of microbial activity below the seafloor. No dissolved sulfate depletion was observed at Site $\mathbf{7 4 4}$ and only a slight depletion was encountered in the uppermost 50 mbsf of Site 738 . Sediments at Site 744 remain oxic to at least $163 \mathrm{mbsf}$. The sulfate reduction occurring at Site 738 requires anoxic conditions, but the low phosphate concentrations and the absence of ammonium in these pore waters reveals the low intensity of the microbial activity. Carbonate precipitation is indicated by the gradual decrease in pore water alkalinity with increasing depth.

Sites 738 and 744 have the lowest major cation fluxes measured on the Kerguelen Plateau. Strong correlations between calcium, magnesium, and potassium concentrations in the interstitial waters collected at both sites indicate that these chemical species behave conservatively within the sediment column. The diffusive fluxes of calcium, magnesium, and potassium are factors of 10,6, and 4, respectively, smaller at Site 738 than at Site 737. These fluxes are even lower at Site 744. No dissolved sodium gradients were observed at the SKP sites. The major cation fluxes on the SKP are driven by chemical potential gradients that result from basement-rock alteration processes. The abundance of authigenic clay minerals in the deeper sediments, secondary minerals filling basalt vesicles in the basement rocks, and low major cation fluxes indicate that water-rock interactions are waning at Site 738.

Silica is being supplied to the interstitial waters at Site 738 from sources at the top and at the bottom of the sediment column. High-resolution sampling provided evidence for significant silica release to the pore waters during the weathering of basement basalt. The low thermal gradients measured on the SKP do not appear to be sufficient for the formation of the opal-CT and quartz chert beds and nodules encountered below $120 \mathrm{mbsf}$ at Site 738. It is likely that they formed millions of years ago.

3. Eastern Kerguelen Sediment Ridge. Sediments ranging from diatom oozes to diatomaceous clays were cored to a total depth of $281 \mathrm{mbsf}$ on a deep-water sediment drift paralleling the southeastern slope of the Kerguelen Plateau. Pelagic and terrigenous sediment sources have resulted in sediment-accumulation 
rates intermediate to those of the NKP and SKP. Sediment organic carbon contents are low (mean $=0.15 \%$ ), but are higher than those encountered on the SKP. Deposition below the regional CCD has produced nearly carbonate-free siliceous sediments. The thermal gradient on the Eastern Kerguelen Sediment Ridge is similar to that measured on the NKP.

Although they contain less organic matter and accumulated at slower rates than the NKP sites, sediments on the Eastern Kerguelen Sediment Ridge exhibit the most robust microbial activity of all the Kerguelen Plateau regions that we have studied. Pore-water alkalinity increases to the highest values measured on the Kerguelen Plateau (6.77 mM) within the first 100 mbsf. The highest dissolved ammonium $(0.50 \mathrm{mM})$ and phosphate (23 $\mu \mathrm{M})$ concentrations were also measured at Sites 745 and 746. Oxidation-reduction potentials begin to decrease near 70 mbsf and indicate that strongly reducing conditions exist below $150 \mathrm{mbsf}$. High pe values (approximately 5) at $20 \mathrm{mbsf}$ imply that aerobic processes may be responsible for most of the phosphate production at that depth. Sediments below $70 \mathrm{mbsf}$ must be anoxic. Bacterial sulfate reduction occurs to at least a depth of $250 \mathrm{mbsf}$.

Major cation concentrations appear to be diffusion controlled in the sediment-pore water system sampled on the Eastern Kerguelen Sediment Ridge. The diffusive fluxes of magnesium, potassium, and calcium at Sites 745 and 746 are intermediate to the fluxes calculated for the NKP and SKP sites. Sites 745 and 746 are unusual, however, in that the downward flux of magnesium is greater than the upward flux of calcium. In addition, the magnitude of the potassium flux is nearly as large as the calcium flux. Charge balance in the interstitial waters is maintained by the strong downward flux of sulfate from the seafloor. The good correlations between dissolved sulfate concentrations and magnesium and potassium concentrations suggest the interesting possibility that the uptake of the latter two species may be partially tied to microbial sulfate reduction and the associated redox changes.

Aqueous silica concentrations steadily increase with increasing depth at Sites 745 and 746 , attesting to the continual dissolution of diatom tests within the sediment column. In contrast to the NKP and SKP sites, no other indications of silica diagenesis are apparent on the Eastern Kerguelen Sediment Ridge.

\section{ACKNOWLEDGMENTS}

This work was supported by a grant awarded to S.R.C. by the JOI U.S. Science Advisory Committee. We would like to thank the crew and technicians aboard the JOIDES Resolution for their help in the collection, processing, and analysis of the samples. Teresa Presser of the U.S. Geological Survey, Menlo Park, CA, was kind enough to let S.R.C. use her atomic absorption spectrophotometer for the pore water sodium and potassium analyses. John Barron, Joris Gieskes, James C. Ingle, Jr., Ole Stig Jacobsen, and Birger Larsen provided helpful reviews of the final manuscript.

\section{REFERENCES}

Alexander, G. B., 1957. The effect of particle size on the solubility of amorphous silica in water. J. Physical Chem., 61:1563-1564.

Barron, J., Larsen, B., et al., 1989. Proc. ODP, Init. Repts., 119: College Station, TX (Ocean Drilling Program).

Berner, R. A., 1980. Early Diagenesis: $A$ Theoretical Approach: Princeton, NJ (Princeton Univ. Press).

Bischoff, J. L., Greer, R. E., and Luistro, A. O., 1970. Composition of interstitial waters of marine sediments: temperature of squeezing effect. Science, 167:1245-1246.

de Lange, G. J., 1984. Shipboard pressure-filtration-system for interstitial water extraction. In Kuijpers, A., Schuttenhelm, R.T.E., Verbeek, J. W. (Eds.), Geological Studies in the Eastern North Atlantic. Mededelingen Rijks Geol. Dienst, 38-2:209-214.
Drever, J. I., 1982. The Geochemistry of Natural Waters: London (Prentice-Hall).

Fanning, K. A., and Pilson, M.E.Q., 1971. Interstitial silica and pH in marine sediment: some effects of sampling procedures. Science, 173: $1225-1231$.

Gieskes, J., Blanc, G., Vrolijk, P., et al., 1989. Hydrogeochemistry in the Barbados accretionary complex: Leg 110 ODP. Palaeogeogr., Palaeoclimatol., Palaeoecol., 71:83-96.

Gieskes, J. M., 1973. Interstitial water studies, Leg 15: alkalinity, pH, $\mathrm{Mg}, \mathrm{Ca}, \mathrm{Si}, \mathrm{PO}_{4}$, and $\mathrm{NH}_{4}$. In Heezen, B. C., MacGregor, I. D., et al., Init. Repts. DSDP, 20: Washington (U.S. Govt. Printing Office), 813-829.

1975. Chemistry of interstitial waters of marine sediments. Annu. Rev. Earth Planet. Sci., 3:433-453.

Gieskes, J. M., and Lawrence, J. R., 1981. Alteration of volcanic matter in deep-sea sediments: evidence from the chemical composition of interstitial waters from deep-sea drilling cores. Geochim. Cosmochim. Acta, 45:1687-1703.

Gieskes, J. M., and Peretsman, G., 1985. Water chemistry procedures aboard JOIDES Resolution-some comments. ODP Tech. Note, 5.

Houtz, R. E., Hayes, D. E., and Markl, R. G., 1977. Kerguelen Plateau bathymetry, sediment distribution and crustal structure. Mar. Geol., 25:95-130.

Iler, R. K., 1979. Chemistry of Silica: New York (Wiley-Interscience).

Isaacs, C. M., 1981. Porosity reduction during diagenesis of the Monterey Formation, Santa Barbara coastal area, California. In Garrison, R. E., Douglas, R. G., Pisciotto, K. E., Isaacs, C. M., and Ingle, J. C. (Eds.), The Monterey Formation and Related Siliceous Rocks of California: Los Angeles (Pacific Section, Soc. Econ. Paleontol. Mineral.), 257-271.

Keller, M. A., and Isaacs, C. M., 1985. An evaluation of temperature scales for silica diagenesis in diatomaceous sequences, including a new approach based on the Miocene Monterey Formation, California. Geo-Mar. Lett., 5:31-35.

Mangelsdorf, P. C., Manheim, F. T., and Gieskes, J.M.T.M., 1970. Role of gravity, temperature gradients, and ion-exchange media in formation of fossil brines. AAPG Bull., 54:617-626.

Manheim, F. T., 1966. A hydraulic squeezer for obtaining interstitial waters from consolidated and unconsolidated sediments. Geol. Surv. Prof. Pap. U.S., 550-C:256-261.

Manheim, F. T., and Sayles, F. L., 1974. Composition and origin of interstitial waters of marine sediments based on deep sea drill cores. In Goldberg, E. D. (Ed.), The Sea (Vol. 5): New York (Wiley), 527-568.

Manheim, F. T., and Waterman, L. S., 1974. Diffusimetry (diffusion constant estimation) on sediment cores by resistivity probe. In von der Borch, C. C., Sclater, J. G., et al., Init. Repts. DSDP, 22: Washington (U.S. Govt. Printing Office), 663-670.

McDuff, R. E., 1978. Conservative behavior of calcium and magnesium in the interstitial waters of marine sediments: identification and interpretation [Ph.D. dissert.]. Univ. of California, San Diego. 1981. Major cation gradients in DSDP interstitial waters: the role of diffusive exchange between seawater and upper oceanic crust. Geochim. Cosmochim. Acta, 45:1705-1713.

McDuff, R. E., and Gieskes, J. M., 1976. Calcium and magnesium profiles in DSDP interstitial waters: diffusion or reaction? Earth Planet. Sci. Lett., 33:1-10.

Moore, G. W., and Gieskes, J. M., 1980. Interactions between sediment and interstitial water near the Japan Trench, Leg 57, Deep Sea Drilling Project. In Scientific Party, Init. Repts. DSDP, 56/57 (Pt. 2): Washington (U.S. Govt. Printing Office), 1269-1275.

Murata, K. J., Friedman, I., and Gleason, J. D., 1977. Oxygen isotope relations between diagenetic silica minerals in Monterey Shale, Temblor Range, California. Am. J. Sci., 277:259-272.

Murata, K. J., and Larson, R. R., 1975. Diagenesis of Miocene siliceous shales, Temblor Range, California. J. Res. U.S. Geol. Surv., 3:553566.

Sayles, F. L., 1981. The composition and diagenesis of interstitial solutions-II. Fluxes and diagenesis at the water-sediment interface in the high latitude North and South Atlantic. Geochim. Cosmochim. Acta., 45:1061-1086.

Sayles, F. L., Manheim, F. T., and Waterman, L. S., 1973. Interstitial water studies on small core samples, Leg 15. In Heezen, B. C., MacGregor, I. D., et al., Init. Repts. DSDP, 20: Washington (U.S. Govt. Printing Office), 871-874. 
Schlich, R., Wise, S. W., Jr., et al., 1989. Proc. ODP, Init Repts., 120: College Station, TX (Ocean Drilling Program).

Suess, E., von Huene, R., et al., 1988. Proc. ODP, Init. Repts., 112: College Station, TX (Ocean Drilling Program).

Walther, J. V., and Helgeson, H. C., 1977. Calculations of the thermodynamic properties of aqueous silica and the solubility of quartz and its polymorphs at high pressures and temperatures. Am. J. Sci., 277:1315-1351.
Williams, L. A., Parks, G. A., and Crerar, D. A., 1985. Silica diagenesis, I. solubility controls. J. Sediment. Petrol., 55:301-311.

Date of initial receipt: 17 November 1989

Date of acceptance: 1 August 1990

Ms 119B-169 